Deep Sea Research Part II: Topical Studies in Oceanography

March 2017, Volume 137, Pages 436-453

http://dx.doi.org/10.1016/i.dsr2.2016.06.006

http://archimer.ifremer.fr/doc/00343/45373/

(c) 2016 Elsevier Ltd. All rights reserved.

\title{
Cold-water coral ecosystems in Cassidaigne Canyon: An assessment of their environmental living conditions
}

\author{
Fabri Marie-Claire ${ }^{1,{ }^{*}}$, Bargain Annaelle ${ }^{1}$, Pairaud Ivane ${ }^{1}$, Pedel Laura ${ }^{1}$, Taupier-Letage $\mathrm{I}^{2}$
}

${ }^{1}$ Ifremer, Département Océanographie et Dynamique des Ecosystèmes, 83500 La Seyne sur Mer, France

${ }^{2}$ Aix Marseille Université, CNRS/INSU, Université de Toulon, IRD, Mediterranean Institute of Oceanography (MIO) UM 110, Antenne de La Seyne, 83507 La Seyne sur Mer, France

* Corresponding author: Marie-Claire Fabri, Tel.: +33 4943048 05; fax: +33 4943044 17. ;

email address : Marie.Claire.Fabri@ifremer.fr

\begin{abstract}
:
The Cassidaigne canyon is one of the two canyons (together with Lacaze-Duthiers) of the French Mediterranean coast in which cold-water corals have settled and formed large colonies, providing a structural habitat for other species. Nevertheless, the communities settled in the Cassidaigne canyon are physically impacted by discharges of bauxite residues.

New information on the distribution of the species Madrepora oculata and the associated species diversity in Cassidaigne canyon was provided by videos and photos acquired in 2013. An area investigated at $515 \mathrm{~m}$ depth harbored a high density of small colonies of $M$. oculata. The water column structure of the area was described by using a CTD transect deployed along the axis of the canyon. High resolution (10 $\mathrm{m}$ and $2 \mathrm{~m}$ ) bathymetric data were collected in the Cassidaigne canyon in 2010 and 2014. Seafloor characteristics were derived from the $10 \mathrm{~m}$ resolution bathymetric data. Data on local hydrodynamic conditions in the first $10 \mathrm{~m}$ above the seafloor were produced by applying the MARS3D hydrodynamic model in the Cassidaigne canyon at a horizontal resolution of $80 \mathrm{~m}$ (CASCANS model configuration). These environmental datasets combined with the geographic coordinates of the known occurrences of dense M. oculata colonies in the canyon allowed establishing a model using the MaxEnt software package to predict the habitat distribution in terms of probability of occurrence.
\end{abstract}

According to the water mass analysis, M. oculata habitats are mainly located in the layer of the Intermediate waters originating from the Eastern Mediterranean Basin. A high concentration of suspended sediment due to the bauxite residues expelled into the canyon was observed in the axis of the canyon where we measured $1 \mathrm{NTU}(2.5 \mathrm{mg} / \mathrm{l})$ at $100 \mathrm{~m}$ above the bottom while concentrations were even higher (2NTU; $5 \mathrm{mg} / \mathrm{l}$ ) closer to the bottom. The habitat suitability model indicates that the living conditions of $M$. oculata can be found in areas of the Cassidaigne canyon where the substratum shows irregularities, slopes and topographic highs. Concerning environmental variables resulting from the hydrodynamic model, temperature and high current velocities were identified as explanatory factors of the distribution of $M$. oculata. Suitable areas for M. oculata habitat settlement were mapped at the scale 
of the canyon.

This study gathers multiple disciplines combined to consider a submarine canyon as a global functioning system and is an approach intended to promote the management of sensitive ecosystems in complex topographic features such as canyons.

Keywords : Habitat suitability model, Biodiversity, Madrepora oculata, Species distribution mapping, Bauxite residues, Mediterranean Sea $\left(\mathrm{N} 43^{\circ}, \mathrm{E} 5^{\circ} 30^{\prime}\right)$ 


\section{1-Introduction}

The Cassidaigne canyon is one of the two canyons (together with Lacaze-Duthiers) of the French Mediterranean coast in which cold-water corals are settled and form large colonies providing a structural habitat for other species. These ecosystems are known to exhibit high species richness and diversity and to increase local diversity (Freiwald et al., 2004).

The communities settled in the Cassidaigne canyon are physically affected by bauxite residue discharges from the aluminum industry. Red bauxite has been discharged into the canyon at 320 m depth (Fig. 1) by the Gardanne aluminum factory since 1967 (Dauvin, 2010; Fontanier et al., 2012) and red mud extends into the abyssal plain more than $50 \mathrm{~km}$ away from the pipe (Fontanier et al., 2014). For 21 years (from 1967 to 1988), the canyon was subjected to the massive discharge of bauxite residues of two different factories. Since 1988 the discharge of red mud has been reduced as one factory stopped production. These residues have been described as having a physical impact on the organisms living in the canyon (Dauvin, 2010; Fabri et al., 2014). Bauxite residue elements like iron, chromium, vanadium and titanium at the surface of the sediment may be potentially toxic for the benthic fauna, but these elements are locked in mineral phases and their bioavailability is questionable (Fontanier et al., 2012). Since 1996, as a result of the Barcelona Convention for the protection of the Marine Environment and the coastal region of the Mediterranean, the quantity of solid particles in the effluent has been progressively reduced, with the objective of completely stopping the outflow by the end of 2015. Nevertheless, the industrial company concerned requested and was granted a six-year authorization starting in January 2016 for a different effluent containing only chemicals and no suspended matter.

Recovery of seafloor integrity by 2020 is one of the objectives of the European Marine Strategy Framework Directive (MSFD). This marine environmental policy drafted in 2008 aims at reducing human impacts on marine waters, by considering that the marine environment is a precious heritage that must be protected, preserved and, where practicable, restored, with the ultimate aim of maintaining biodiversity and providing diverse and dynamic oceans and seas which are clean, healthy and productive (European Parliament, 2008). These objectives require an assessment of the status of Vulnerable Marine Ecosystems (as defined by the UN General Assembly) and particularly of their spatial distribution.

Cold-water coral colonies were located in the Cassidaigne canyon during several recent oceanographic cruises (Fabri et al., 2014), though the production of distribution maps was hampered by the limited coverage of videos recorded during submersible dives. The increasing need to manage and protect these vulnerable cold-water coral ecosystems has motivated general interest in obtaining optimal habitat requirements. Predictive habitat mapping is a fairly recent way of working on the extent of benthic populations, as it benefits from the spatial information provided by multibeam echosounder technologies (Wilson et 
al., 2007). Cold-water corals are frequently reported (1) from sites with locally accelerated currents, which enhance seabed food supply and limit the negative effects of sediment burial (Davies et al., 2009), and (2) in a water density envelope favoring larvae transport (Dullo et al., 2008). Therefore hydrodynamic environmental variables were added to the predictive habitat mapping. These variables have already been shown to improve habitat model predictions (Mohn et al., 2014; Rengstorf et al., 2014). The purpose of this paper is to illustrate the use of predictive modeling tools, which produce continuous maps of the potential distribution of habitats from a limited number of observation points and a full coverage of environmental data. The integration of bottom hydrodynamic parameters, terrain information and species occurrences in statistical models is an innovative way of predicting suitable habitats for deep-sea benthic species (Rengstorf et al., 2014).

Our work is aimed at providing new information on the Madrepora oculata habitat in the Cassidaigne canyon, using: (1) video and photographic data, and a $2 \mathrm{~m}$ resolution bathymetric map in the head of the canyon; (2) in situ water column parameters and turbidity measurements in the axis of the canyon; (3) seafloor characteristics derived from a $10 \mathrm{~m}$ resolution bathymetric map of the entire canyon; (4) hydrodynamic parameters resulting from a high resolution hydrodynamic model; (5) the predictive distribution of $M$. oculata habitats in terms of probability of occurrence.

\section{Materials and methods}

\subsection{Study area}

The Cassidaigne canyon is located $8 \mathrm{~km}$ south of the coast of the Provence region between Marseille and Toulon (France) and is situated between the Gulf of Lion and the Ligurian Sea (Fig. 1). This canyon consists of an incision $20 \mathrm{~km}$ long and a depth reaching $1700 \mathrm{~m}$ (Fig. 1). Its abrupt flanks are asymmetric and mainly characterized by the nature of the rocks subcropping on the margin during its formation (Tassy et al., 2014).

The study area covers the western flank of the Cassidaigne canyon $\left(43^{\circ} 10^{\prime} \mathrm{N}, 5^{\circ} 30^{\prime} \mathrm{E}\right)$. Several locations on this flank are covered with M. oculata (Fig. 1). Two of these locations, in this paper named "Cassis-500" (at 515 meters depth) and "Cassis-200" (from 200 to 215 meters depth), are located in the head of the canyon, while a third one, named the "Wall" (from 320 to 480 meters depth), is located at the exit of the canyon and was previously described as a vertical escarpment colonized by recently settled dense colonies of $M$. Oculata (Fig.1) (Fabri et al., 2014).

The general circulation (the Northern Current) flows mainly westward along the continental slope of the eastern Gulf of Lion. The Northern Current is wide, shallow and weak during summertime; narrow, deeper and stronger during wintertime (Millot and Taupier-Letage, 2005). The detailed study of the bay of Cassis by Alberola and Millot (2003) showed that the circulation is complex, as it is forced by both the Northern Current and the wind. However, during wintertime, the isopycnals are very steep, and the mean circulation is mainly westward on the whole water column at both the canyon head and over the shelf. The Northern Current is therefore very close to the shore, and its mesoscale activity, namely meanders, penetrates deep into the bay and induce high variability (in both current intensity and direction). During stratified conditions, the westward Northern Current is limited to the surface layer, while the mean circulation in the deeper layer is eastward at the canyon head (Alberola and Millot, 2003). 
The circulation is also constrained by two prevailing winds on the Gulf of Lion shelf: north-northwesterly winds (upwelling-favorable winds) and southeasterly winds (downwelling-favorable winds). Under stratified conditions, the north-westerly to westerly winds, called Mistral, lead to the southward displacement of lighter (warmer) surface waters to the open sea, generating upwellings at six locations in the Gulf of Lion (Millot, 1990). In relation to wind and coast-line direction and, possibly, to interactions with the canyon circulation, the most intense upwelling of the Gulf of Lion is centered within the Cassidaigne canyon (Alberola and Millot, 2003). During the upwelling events, deep- and thus colderwater is channeled along the canyon axis up onto the shelf. However, during downwelling events (mostly in winter), this process is reversed and bottom currents can carry huge amounts of sediment and organic matter to the deep ocean as they scour the shelf and slope seafloor.

\subsection{Video data and species distribution}

\subsubsection{New video records of Cassidaigne canyon}

In October 2013 we had the opportunity to dive in the Cassidaigne canyon (submersible Nautile dive 1852-10, cruise ESSNAUT 2013, R/V L'Atalante, P.I. P. Triger), check for the presence of $M$. oculata at the Cassis-500 site and collect new data at Cassis200 site. (Table 1, Fig. 2). The submersible Nautile was equipped with two cameras. One was fixed to a pan and tilt mount used by the pilots and equipped with a zoom. The other was fixed and mounted on the right side of the submersible. Both cameras recorded videos continuously onto a hard disk. No lasers allowing in situ measurements were available during this dive. The navigation of the Nautile was derived from the acoustic USBL positioning system (POSIDONIA) and the dead reckoning navigation provided by the inertial navigation system (PHINS III) coupled with a Doppler velocity sensor.

\subsubsection{Dataset used for predictive mapping}

The occurrences of $M$. oculata considered in this study are from the large set of videos recorded by the Comex and Ifremer submersibles already described (Fabri et al., 2014) and from the new video records of the Nautile dive 1852-10 described in this work (Table 1). For the analyses, we distinguished scattered colonies (i.e. one single colony on a 10x10 pixel) from dense colonies and decided to keep only occurrences of dense colonies in order to map M. oculata habitat distribution rather than M. oculata species distribution (Fig. 1). Colonies were located at three sites: Cassis-200 (at 515 meters depth), Cassis-500 (from 200 to 215 meters depth) and the Wall (from 320 to 480 meters depth) previously described as a vertical escarpment colonized by recently settled dense colonies of M. oculata (Fabri et al., 2014).

Occurrences of $M$. colonies were plotted from video records using Adelie-GIS and Adelie Video (CIfremer) (Fig. 2). The detailed methodology is described in Fabri et al. (2014). The absence of lasers on the continuously recording camera prevented the calculation of surface areas and densities.

Presence-data points were reduced to one point per raster cell $(10 \times 10 \mathrm{~m})$ in order to avoid repetition and spatial autocorrelation in further analyses. 


\subsection{Environmental in situ measurement}

\subsubsection{Water mass parameters}

Water column parameters (temperature, conductivity and hence salinity) were collected using a SeaBird SBE 19 PlusV2 CTD probe deployed from the ship during the BATHYCOR1 cruise in 2014 (R/V L'Europe, AUV Idef'X, P.I. MC. Fabri) (Fig. 1, Table 2). Data were processed using the SeaBird software. A potential temperature versus practical salinity (theta-S) diagram was obtained using Ocean Data View freeware (Schlitzer, 2016). Data from the CTD transect A to J were considered for this diagram (Fig. 1).

\subsubsection{Turbidity and Suspended Sediment Concentration (SSC)}

An autonomous optical backscatter sensor (NKE STBD 1200) was installed on the CTD probe in 2014 during the BATHYCOR1 cruise in order to collect ten vertical turbidity profiles along the canyon axis ( $23^{\text {th }}$ August 2014 ) (Fig. 1, Table 2 ). The profiles had to be interrupted at an average altitude of 40 to $70 \mathrm{mab}$ ( $\mathrm{m}$ above the bottom) for safety issues.

The sensor was previously calibrated with Formazin as recommended by NKE marine electronics (www.nke-marine-electronics.com). The results are given in Nephelometric Turbidity Units (NTU).

In order to link the NTU values to the Suspended Sediment Concentration we built a calibration curve of our sensor using bottom sediment that had been previously sampled with a push core (СT9) during ROV dive 407-11, cruise ESSROV2010 (Fontanier et al., 2012). Particle grain sizes were analyzed using laser diffraction and median grain size (D50) was 11 $\mu \mathrm{m}$, although some particles were as large as $150 \mu \mathrm{m}$ (see (Fontanier et al., 2012) - figure 2D). We first measured the turbidity in a 10-liter container of distilled water in which we added $\mathrm{NaCl}$ to obtain a salinity concentration of $38.4 \mathrm{~g} / \mathrm{l}$. We checked the concordance with a laboratory turbidimeter (Hatch 2100n IS - Iso Method 7027) to confirm the starting point (0.04 NTU). Then we progressively added a known quantity of particles in the container of salty distilled water. After each addition of particles, the water was mixed and left for 30 seconds before recording the turbidity every second for 5 minutes. We tried to keep a uniformly mixed suspension with no sediment settling but failed to prevent large particles from sinking to the bottom of the container. We then calculated the mean of the recorded turbidity in NTU for each known concentration of particles. This allowed building a calibration curve, starting from 0.04 NTU to 3 NTU, which corresponded to the range of our in situ values (online supp. mat. Fig. A1).

\subsection{Bathymetric data}

\subsubsection{Data collection and processing}

Acoustic data were collected during two cruises (Table 1). We used the hull-mounted Multibeam Echo Sounder (MBES) Reson $7150(24 \mathrm{kHz})$ to collect the bathymetric data of Cassidaigne Canyon during the ESSROV 2010 cruise (Table 1, R/V Pourquoi Pas?, P.I. P. Simeoni) to build the map of the whole canyon at $10 \mathrm{~m}$ resolution. We also collected data to build a $2 \mathrm{~m}$ resolution map in the northern part of the canyon on Cassis- 200 and Cassis-500 areas during the BATHYCOR1 cruise in 2014 with a Kongsberg EM2040 MBES (200 kHz) mounted on the Autonomous Underwater Vehicle (AUV) Idef'X. Post-processing of MBES data was carried out with the Ifremer package CARAIBES @ Ifremer (CARtography Adapted 
to Imagery and BathymEtry of Sonars and multibeam echosounders, www.ifremer.fr/caraibes). Two bathymetric maps were created, one covering the whole canyon at $10 \mathrm{~m}$ resolution (Fabri, 2015) and the other one covering only a part of the canyon head at $2 \mathrm{~m}$ resolution.

As the Cassidaigne canyon is very steep the physical backscatter values were not easily retrieved, even after compensating the sensor characteristics, thus they are not considered in this paper.

\subsubsection{Terrain variables derived from bathymetry}

To assess the seafloor characteristics we considered the $10 \mathrm{~m}$ resolution map of the Cassidaigne canyon. We limited our study to the canyon: the pixels corresponding to the continental shelf were set to "No Data" (pixels having bathymetric values $<180 \mathrm{~m}$ ).

A set of 14 variables derived from this bathymetry was produced using the Benthic Terrain Modeler ArcGIS extension for ArcGIS 10.2 (Wright et al., 2005). It included the Bathymetric Position Index (BPI) indicating whether any particular pixel forms part of a positive (e.g. crest) or negative (e.g. hollow) topographic feature of the surrounding terrain at six different outer-radius window sizes $(3,9,17,25,33,65$ pixels); the seabed slope; the curvature (overall, perpendicular to the slope (plan) and in the direction of the slope (profile)); terrain ruggedness (the mean of the absolute values of the differences between the depth value of a central pixel and its surrounding cells, encoding small scale variations in the seabed) at 3, 5 and 11 pixel window sizes; and another kind of rugosity which is the surface-area-to-planar-area index (the ratio of the surface area to the flat area across the neighborhood of a central pixel) (Rengstorf et al., 2014; Wilson et al., 2007).

\subsection{Hydrodynamic modeled environment}

\subsubsection{Hydrodynamic model}

The MARS3D (Lazure and Dumas, 2008) hydrodynamic model (version V10.2) was set up for the Cassidaigne canyon over the period September-December 2013, using a model nesting strategy (Fig. 3) to increase the horizontal model resolution. The CASCANL configuration uses a 170×197 mesh grid at a horizontal resolution of $400 \mathrm{~m}$, and 60 vertical generalized sigma levels (which are refined close to the bottom and the surface). The general circulation forcing at open boundaries was provided by the operational MARS3D MENOR model configuration of the NWMED (Garnier et al., 2014; Pairaud et al., 2014). The atmospheric forcing (wind, heat fluxes, rain) was provided by the ARPEGE (Météo-France) model. Using the refined bathymetry at $10 \mathrm{~m}$ resolution (ESSROV 2010), a two-way nesting was performed in the CASCANL configuration, with an embedded zoom at $80 \mathrm{~m}$ horizontal resolution centered on the canyon (CASCANS configuration, 258x363 mesh grid). This nesting was performed using the AGRIF ('Adaptive Grid Refinement In Fortran') tool (Debreu et al., 2008), and took into account the effect of fine scale bathymetry over bottom currents and retroactions over a larger scale. Comparisons of model results with observations were performed in line with the approach of Pairaud et al. (2011) who used MARS3D to study the hydrodynamics of the Marseille area, including the canyon. Comparisons of the model results with satellite images (ocean color and sea surface temperature) and in situ data (hydrology and current) in the first 200 meters of the water column were made in order to validate the model both in terms of processes (through their physical signature patterns) and statistically (through quantitative comparisons at fixed stations or along vessel transects). 
The model provided hourly information on the hydrology (temperature, salinity, density) and dynamics (currents) of the area. The first sigma levels near the sea bottom (roughly 10 meters and up to 70 meters in the deepest areas) were considered over a period of four months (autumn 2013) for the predictive habitat mapping.

\subsubsection{Validation of the hydrodynamic model}

To assess the model's ability to reproduce temperature variations in the surface layer, temperature time series from the T-MedNet network were used (www.t-mednet.org). The data (provided by the Institute Pytheas) were collected at the Cassidaigne station $\left(5^{\circ} 32.74^{\prime} \mathrm{E}\right.$, $43^{\circ} 08.74^{\circ} \mathrm{N}$ ) using HOBO Water Temp Pro v2 data loggers fixed every $5 \mathrm{~m}$ along a rocky wall at depths ranging from 5 to $45 \mathrm{~m}$ (Fig. 1). The temperature sensors were set to collect hourly records with a precision of $0.2^{\circ} \mathrm{C}$ and a resolution of $0.02{ }^{\circ} \mathrm{C}$. The data used from these time series span from September to December 2013.

\subsubsection{Hydrodynamic variables resulting from the hydrodynamic model}

A set of eight hydrodynamic variables near the seafloor was obtained from the CASCANS model at a resolution of $80 \mathrm{~m}$. These data were interpolated using the natural neighbor method available in Arc Map v10.3 (ESRI) to match the bathymetric raster of $10 \mathrm{~m} * 10 \mathrm{~m}$ before being used for further analyses. This allows taking into account variables derived from the higher resolution bathymetry even though the resolution of the hydrodynamic patterns is only $80 \mathrm{~m}$. The hydrodynamic variables considered in our study were the maximum and mean values of current velocity, seawater temperature, salinity and density.

\subsection{Statistical analyses}

The set of environmental variables ( 14 terrain variables and 8 hydrodynamic variables) was extracted from the 22 rasters at each $M$. oculata presence point, using $\mathrm{R}$ freeware. The dataset containing presence points was composed of 22 variables and 85 observations.

Two matrices were considered: (1) the whole set of environmental variables in the study area under $180 \mathrm{~m}$, and (2) the values of those environmental variables only at the presence points.

Principal Component Analyses (PCA) and hierarchical clustering were performed on the input variables using XLSTAT 2015 for Excel (Copyright (C) 2015 Addinsoft) in order to group them and identify the main one for each group. A PCA was first performed on each group of variables separately to better understand the detailed relations between terrain variables on the one hand and between hydrodynamic variables on the other. Then a global PCA was performed on all the variables together in order to identify the non-correlated ones to build the final model. Box plots were calculated using $R$ freeware.

\subsection{Predictive habitat mapping}

\subsubsection{Maximum Entropy modeling}

The free MaxEnt software package (Phillips et al., 2006) was used to build a model that linked every $M$. oculata observation to a set of environmental conditions (seafloor characteristics and hydrodynamic conditions) and to predict the distribution of the habitat in terms of probability of suitability for $M$. oculata distribution. The contribution of each 
variable to the habitat suitability model was also determined (Elith et al., 2011; Merow et al., 2013; Phillips et al., 2006; Phillips et al., 2004). This method presents the advantage of finding the distribution that agrees with everything known about the distribution of the habitat without making any assumptions about what is not known. MaxEnt has been frequently used for cold-water coral predictive habitat mapping (Davies and Guinotte, 2011; Howell et al., 2011; Rengstorf et al., 2012; Ross and Howell, 2013; Tittensor et al., 2009; Tittensor et al., 2010; Vierod et al., 2014; Yesson et al., 2012) and found to outmatch other statistical models such as ENFA (Ecological-Niche Factor Analysis) in assessing species/habitat distribution with presence-only data (Elith et al., 2006; Tittensor et al., 2009), even with small sample sizes (Pearson et al., 2007; Wisz et al., 2008). MaxEnt is a general-purpose machine-learning method aimed at estimating a target probability distribution by finding the probability distribution of maximum entropy (i.e. that which has the widest spread, or is closest to uniform), subject to a set of constraints that represent the incomplete information on the target distribution. MaxEnt formalizes the principle that the estimated distribution must agree with everything that is known but should avoid placing any unfounded constraints (Elith et al., 2011; Phillips et al., 2006; Phillips et al., 2004).

The subset of non-correlated environmental variables (see section 2.6) was composed of the pre-selected environmental conditions derived from the bathymetry and the preselected environmental conditions resulting from the hydrodynamic model. This preselection is a fundamental step in enhancing the accuracy and predictive power of the model (Elith and Leathwick, 2009; Guisan and Zimmermann, 2000; Ross and Howell, 2013).

We implemented these pre-selected independent variables in the MaxEnt version 3.33 (https://www.cs.princeton.edu/ schapire/maxent/) to build the predictive habitat model of M. oculata distribution in the Cassidaigne canyon.

The default settings for the convergence threshold $\left(10^{-5}\right)$ and the maximum iteration (500) were left unchanged. The regularization multiplier was finally set to 3 after different trials to reduce over-fitting (i.e. to ensure that predictions approximately satisfy constraints rather than satisfy them exactly). The prevalence was set to 0.7 (i.e. the probability of presence at ordinary occurrence points) to obtain higher habitat suitability values in known areas of coral occurrences. The constraints were expressed in terms of simple functions (transformation) of the environmental variables, called features. The selected feature class was "Hinge only", which allowed a change in gradient of the response (Elith et al., 2011), providing more succinct approximations of the species' true distribution probability with high predictive power and less complexity in the model (Phillips and Dudik, 2008). The default maximum number of background points (10 000) was left unchanged. These points were randomly sampled by the software and treated as pseudo-absences for the evaluation of the model (Elith et al., 2011).

\subsubsection{Model evaluation}

The MaxEnt model was used with a k-fold cross-validation procedure implemented directly in the MaxEnt software, with 10 randomly generated partitions to compare training datasets and testing datasets. This allowed obtaining out-of-sample estimates of predictive performance and estimates of uncertainty around fitted functions (Elith et al., 2011). The accuracy of the model was then evaluated using the Area Under the receive operator Curve (AUC) using presence and background points (Elith et al., 2011). The AUC value, ranging from 0 to 1 , indicates how well the model fits the data: a test AUC below 0.5 means that the model is no better than random, an AUC of 1 means the model is ideal, while an AUC higher 
than 0.7 can be considered as appropriate. AUC values have been criticized for being biased by the spatial extent of the study area (Lobo et al., 2008) so we also applied test gain, which is a measure of goodness of fit, an estimation of how close the model is to the test samples (if the gain is 2 , it means that the average likelihood of the presence samples is $\exp (2) \approx 7.4$ times higher than that of a random background pixel (http://www.cs.princeton.edu/ schapire/maxent)).

\subsubsection{Assessment of variable importance within the model}

Jackknife plots and variable response curves were processed to assess each variable importance. Jackknife tests compare the predictive performance of the model with only one of each type of variable and then with all the variables except the variable tested first.

\subsubsection{Predicted distribution}

The mean model of the 10 replicates was then applied for habitat suitability mapping. We used MaxEnt's 10th percentile (training presence value) threshold as the cut-off for $M$. oculata presence and absence. Grid cells with a predicted habitat suitability value above this threshold were considered suitable for M. oculata; cells with a value below this threshold were considered unsuitable.

\section{Results}

\subsection{New video records and species distribution in Cassidaigne canyon}

\subsubsection{Cassis-500 site}

In 2013 we went to the Cassis-500 site and observed and recorded large colonies of cnidarians (Fig. 4). When we arrived on the bottom red mud disturbed by Nautile's motors was in suspension and it was necessary to wait for the particles to settle before continuing the dive. Nautile navigated along a step (several meters high) for 80 meters. During this navigation videos were recorded to view the underside and top surface of an overhang.

On the top of the ledge the most obvious feature was the alignment of several large colonies of Callogorgia verticillata (Fig. 4A). Colonies of $M$. oculata around $40 \mathrm{~cm}$ in height with a large base covered with red mud were growing out of the edge of the overhang (Fig. 4B). Small colonies around $20 \mathrm{~cm}$ in height and even smaller ones covered the ceiling of natural caves and cavities under the overhang (Fig. 4C). These downward growing colonies had very unusual long, thin branches (Fig. 4D). These specimens were very white, suggesting they were alive, contrary to the dead colonies of M. oculata on the top of the overhang which were completely covered with red mud (only the skeletons could be recognized). Few coralassociated species could be observed in the red mud.

Three species of glass sponges (Hexactinellidae) were seen in abundance on vertical parts of the ledge. The specimens were recognized on in situ photographs, but no specimen was sampled which would have allowed identification. Several specimens of the glass sponge Tretodictyum cf. tubulosum and Farrea sp. were also recognized from the video (Fig. 4E and $4 \mathrm{~F}$ ) on the basis of their known morphology and distribution (Reiswig, 2014; Van Soest, 2015). Another Hexactinellid was seen in high abundance on the vertical part of the ledge, and specimens seemed to have settled on M. oculata skeletons. The body form of this sponge is a sac with a distal orifice, suspended from a vertical support. These sponges were identified as Oopsacas cf. minuta, known to be widely distributed in the deep western 
Mediterranean sea (Bakran-Petricioli et al., 2007). A very small bright yellow encrusting sponge was identified as Hexadella cf. crypta (Desmospongiae) (Fig. 4E) according to (Reveillaud et al., 2012).

Five cnidarians other than $M$. oculata and $C$. verticillata could be recognized from the video. The solitary scleractinian Desmophyllum dianthus was present in abundance, and maybe Caryophyllia sp., but this is less certain (Fig. 4H). One antipatharia (Antipathes cf. dichotoma) and three gorgonians or Alcyonaceans (Viminella flagellum, Acanthogorgia hirsuta and Plexauridae spp.) could also be recognized (Fig. 4C, 4G).

The decapod crustacean Munida $s p$. was seen very frequently on the vertical parts of the ledge.

\subsubsection{Cassis-200 site}

Videos recorded in 2010 on Cassis-200 provided broad views of the outcrop on which $M$. oculata colonies were seen facing the current (Fig. 5A). The opposite side of the structure was covered with Viminella flegellum and many encrusting sponges.

The Nautile dive in 2013 (dive 1852-10) explored the northeastern part of the Cassis-200 site (Fig. 2C). The area was covered with large M. oculata colonies together with antipatharians (Leiopathes glaberrima, Antipathes cf. dichotoma, Antipates cf. subpinnata), gorgonians (Eunicella sp.) and very small colonies of Corallium rubrum (Fig. 5C). A wide diversity of sponges as well as some echinoderms (Cidaris cidaris, Echinus melo), holothurians and sea stars (asteroidea) were also present (Fig. 5B, 5C). No Paramuricea sp. were observed on this northeastern part of the Cassis-200 site (Fig. 5D) while they were numerous on the western part (Fabri et al., 2014).

\subsubsection{Coral occurrence dataset used for predictive mapping}

Using all the M. oculata observation data points available on the Cassidaigne canyon (i.e. from Fabri et al (2014) and from the Nautile dive 1852-10), we identified 85 pixels holding dense coral colonies distributed on the two locations described in this paper (Cassis-200, Cassis-500) and on the third one (the Wall) described previously as a vertical escarpment colonized by recently settled dense colonies (Table 1, Fig. 1).

\subsection{Environmental data from in-situ measurements}

\subsubsection{Water mass structure in August 2014}

The potential temperature versus practical salinity (theta-S) diagram illustrates the water masses characteristic of the area in August 2014, taking into account the CTD profiles from the shelf to the deep sea acquired during the BATHYCOR1 cruise (Fig. 6).

In the surface layer the Atlantic Water (AW, $\theta>\sim 13.5^{\circ} \mathrm{C}$; $\mathrm{S}<\sim 38.3$; density $<\sim 28.6 \mathrm{~kg} . \mathrm{m}^{-3}$ ) is transported by the Northern Current over the shelf and over the canyon head. Under stratified summertime conditions and in the absence of Mistral wind the surface temperatures reached $24^{\circ} \mathrm{C}$. Below, saltier and warmer water $\left(\theta>\sim 13.3^{\circ} \mathrm{C}, \mathrm{S}>\sim 38.4\right)-$ previously referred to as Levantine Intermediate Water and renamed Eastern Intermediate Water (EIW), as it results from the mixing of the intermediate waters exiting the Eastern Basin (Millot, 2013), filled the layer from $\sim 250 \mathrm{~m}$ down to $\sim 700 \mathrm{~m}$. The underlying cold Western Mediterranean Deep Water (WMDW, $\theta<\sim 13.2^{\circ} \mathrm{C}$ ) was found in the deeper part of the domain under $800 \mathrm{~m}$ depth. 


\subsubsection{Turbidity and Suspended Sediment Concentration (SSC)}

The ten vertical turbidity profiles collected at the CTD stations in the canyon axis show turbidity values ranging from 0.15 NTU on the shelf and in the surface layer to 2.2 NTU at the bottom of the canyon exit (Fig. 7).

Turbidity values were very low above $300 \mathrm{~m}$ depth $(<0.2 \mathrm{NTU})$ on the whole set of profiles (on the shelf, flanks and canyon axis) while the stations located downstream of the bauxite residue effluent in the canyon axis (Stations $A, B, C, D, E$ ) displayed maximum turbidity in the lower layer (Fig. 7).

Maximum turbidity values were measured above the bottom at the deepest station (A), exceeding 2 NTU at the canyon exit. However, the maximum particle load does not always lie just above the bottom: at stations $B$ and $C$ there was an intermediate maximum between 600 and $700 \mathrm{~m}$, and to a lesser extent at $\sim 500 \mathrm{~m}$ at station A. The turbid layer was thicker closer to the pipeline effluent. As the effluent is a mixture of particles of different sizes (Fontanier et al., 2012) in freshwater, it is expected that downstream it generates several layers according to water density and particle size.

The east-west orientation of the bathymetry around stations C, E, G might also contribute to the dispersion of the particles (cross-axis current), as shown by the multilayered turbidity profile at station $\mathrm{K}$ (bottom depth $770 \mathrm{~m}$; not shown). Thus the coral colonies at Cassis-500 are impacted by the turbidity of the red mud (Fig. 4).

According to the calibration of our sensor, we roughly correlated a turbidity value of 1 NTU to an SSC $=0.6 \mathrm{mg} / \mathrm{l}$, and the maximum measurement of around $2.5 \mathrm{NTU}$ to an SSC $=2 \mathrm{mg} / \mathrm{l}$.

\subsection{Bathymetric and derived data}

\subsubsection{Morphology}

The $10 \mathrm{~m}$ resolution bathymetric map (Fig. 1) reveals a morphology in three parts: (1) the head of the canyon results from the intersection of several erosive valleys presenting singular axis directions; (2) in the intermediate domain the incision is deeper and reaches $1200 \mathrm{~m}$; (3) then the canyon incision reaches $1700 \mathrm{~m}$ depth and is pinched against an E-W bathymetric high, before opening into the basin $7 \mathrm{~km}$ seawards, to the SE (see details in Tassy et al. (2014)).

M. oculata colonies can be located precisely on the $2 \mathrm{~m}$ resolution map: (1) at the Cassis-500 site along a step clearly identified on the bathymetry (Fig. 2B); (2) at the Cassis200 site on a small platform highlighted by the $215 \mathrm{~m}$ isobath (Fig. 2C).

\subsubsection{Data derived from Bathymetry}

The 14 rasters derived from the $10 \mathrm{~m}$ resolution bathymetry were analyzed statistically. A PCA was compiled using the Spearman rank correlation on the matrix of these terrain variables only at the presence point locations in order to select the non-correlated variables to build the habitat suitability model (online supp. mat. Fig. A2). Since the model was built on the presence points only, the variable correlation was only tested at the presence points.

The two first components of the PCA explained $54 \%$ and $23 \%$ of the variability, respectively. The first axis is driven by the variables encoding for terrain irregularities (Bathymetric Position Indexes (PBIs) and Ruggedness) and two curvatures (overall and flat) opposed to the profile curvature. The second axis is driven by the slope and the surface- 
area-to-planar-area. The third axis, explaining $12 \%$ of the variability, separates the small scale Bathymetric Position Index (BPI on 3 pixels) and both curvatures from the other terrain irregularity indexes.

We grouped together variables with $70 \%$ similarity from the dendrogram for the hierarchical clustering of terrain variables, using mean linking based on the Spearman rank correlation similarity matrix (online supp. mat. Fig. A2). The information derived from the bathymetry could then be summarized by the five following variables: Profile curvature, Slope, small scale BPI (on 3 pixels), large scale BPI (on 25 pixels) and Ruggedness (on 11 pixels).

Box plots of these five environmental variables derived from the bathymetry are presented for the total coverage $(>180 \mathrm{~m}$ ) and at the presence points of the species (Fig. 8). From these box plots it can be seen that $M$. oculata is located in areas where the statistical parameters (mean +/- SD) of Ruggedness on 11 pixels (0.12 +/- 0.067), Slope (47.6 +/- 25.3) and large scale BPI (on 25 pixels) $(68+/-38)$ show globally higher values than those on the total area (no statistic comparisons were computed). This result shows that $M$. oculata settles preferentially on areas where the substratum presents irregularities, steep slopes and elevated features (topographic highs) at a resolution of $250 \mathrm{~m}$. Small scale BPI and profile curvatures do not show strong differences at the presence points of the species.

\subsection{Hydrodynamic parameters resulting from the model}

\subsubsection{Validation of model hydrology and currents on the shelf}

The statistical values of the hydrological and current parameters from the first $10 \mathrm{~m}$ layer above the bottom resulting from the CASCANS model were intended for use in the habitat model.

In order to evaluate the model outputs, model temperatures from CASCANL and CASCANS were compared to temperatures recorded in-situ at the T-MedNet Cassidaigne station east of the canyon head. It can be seen that the water is stratified in summer, with warm temperature in the upper layers (Fig. 9). As wind events intensify during fall, the water column tends to homogenize and get colder. Upwellings like that of 15 September 2013 (Fig. 9) contribute to homogenization by bringing colder waters from deeper layers, inducing cooling throughout the water column at the Cassidaigne station (a $10^{\circ} \mathrm{C}$ drop at $10 \mathrm{~m}$ depth). The signature of the other Mistral upwelling event on 15 November 2013 is also reproduced by the models, although with lower cooling. The episodes of subsequent mixing due to strong winds other than Mistral show the erosion of the thermocline and the increase of temperature in the deeper layers (see figure 3 of Alberola and Millot [2003]). Thus the model reproduces the temperature variability well along both depth and time for CASCANL and CASCANS (Fig. 9). But the model temperature variability is less marked than that observed. Also, the model underestimates temperature in early September and overestimates it in late October to November (at least). This pattern is similar to previous results obtained from a different model configuration in this area (Pairaud et al., 2011), suggesting the need to take better account of air-sea interaction. Most of the in-situ data were available in shallow areas characterized by strong temporal variability. As the ocean bottom is less affected by rapid air-sea interaction, this drawback of the model may be limited to the surface layer, although further comparisons with deep mooring measurements are necessary to confirm better model behavior at depth. 
The mean current and mesoscale variability calculated using current variance ellipses computed over this 4-month period are shown (Fig. 10). In the upper layer the mean currents are weaker close to the coast and above the canyon. They are oriented mainly north-westward on the eastern part of the shelf, as a result of the spreading of the Northern Current over it (Fig. 10A). The eccentricity and size of the ellipses over the shelf for depths greater than $\sim 100 \mathrm{~m}$ are mostly comparable to those of the Northern Current. These results are in agreement with previous findings ((Alberola and Millot, 2003)-figure 9). The canyon axis appears different from the shelf, with a weak mean current varying slightly in this subsurface layer. The circulation just above the bottom is mainly constrained by the bathymetry (Fig. 10B).

\subsubsection{Hydrodynamics of the bottom layer used for habitat modeling}

Current maxima are located over the western upper slopes of the canyon, in areas where cold-water corals have been observed on the Cassis-200, Cassis-500 and Wall sites (Fig. 10C). The $400 \mathrm{~m}$ resolution CASCANL model configuration did not show these current maxima but the high horizontal resolution CASCANS model did represent the local effects of the abrupt topography on the currents (Fig. 10B, 10C). A secondary maximum appears at the exit of the canyon at $\sim 1900 \mathrm{~m}$ depth. Another maximum appears at the bottom of the canyon (along the axis) (Fig. 10C).

\subsubsection{Analysis of variables resulting from the hydrodynamic model}

The eight rasters resulting from the hydrodynamic model were statistically analyzed. A PCA was compiled on the matrix of those hydrodynamic variables only at the presence points (online supp. mat. Fig. A3).

The two first axes of the PCA explained $83 \%$ and $15 \%$ of the variability, respectively. The first axis representing hydrology shows water density and salinity as a function of temperature, while the second axis representing hydrodynamics was driven by current velocity.

We grouped together variables with $70 \%$ similarity from the dendrogram for hierarchical clustering, using mean linking based on the Spearman rank correlation similarity matrix (online supp. mat. Fig. A3). The information derived from the hydrodynamic model could then be summarized by the three following variables: (1) for the hydrology we decided to keep the maximum temperature; (2) for the hydrodynamics we decided to keep both the mean and max current velocity values because they were separated by the third axis of the PCA (explaining only $1.4 \%$ of the PCA).

Box plots of these three environmental variables resulting from the hydrodynamic model (maximum temperature, mean and maximum current velocity) for autumn 2013 are presented for the total coverage $(<180 \mathrm{~m})$ and at the presence points of the species (Fig. 11). From these box plots it can be observed that presence points are located in areas where values (mean +/- SD) of maximum temperature $\left(14.36{ }^{\circ} \mathrm{C}+/-0.53\right)$ are globally higher than the ones for the total area under $180 \mathrm{~m}\left(13.70^{\circ} \mathrm{C}+/-0.65\right)$, which is consistent with the fact that $M$. oculata colonies are located in the upper part of the depth range values (between 200 and $550 \mathrm{~m})$. This implies that they are located in warmer water than that areat depths. Mean salinity values $(38.56+/-0.04)$ and mean temperature values $(13.71+/-0.25)$ corresponding to presence points show that $M$. oculata lives at the depth of the EIW in the Cassidaigne canyon (see section 3.2.2). With regard to current velocity, the presence points harbor a very narrow range of mean current velocity $(0.019 \mathrm{~m} / \mathrm{s}+/-0.003)$, with values 
corresponding to the lower values of the total dataset range $(0.026 \mathrm{~m} / \mathrm{s}+/-0.040)$. This shows that $M$. oculata is located in areas where a gentle mean current circulates. Concerning the maximum current velocity values, both ranges (total and only $M$. oculata) show considerable variability. However, it can be seen that half of the presence dataset (median = $0.218 \mathrm{~m} / \mathrm{s}$ ) contains values higher than $75 \%$ of the total dataset (third Quartile $=0.187 \mathrm{~m} / \mathrm{s}$ ), which suggest that $M$. oculata are thus preferentially located in areas where occasionally a strong current occurs.

\subsection{Predictive habitat mapping}

\subsubsection{MaxEnt modeling}

The global PCA and hierarchical clustering performed on all the variables together (22) enabled us to confirm that the set of environmental variables identified from the PCA on the terrain variables and on the hydrodynamic variables were non correlated together (online supp. mat. Fig. A4). MaxEnt was thus run with a set of five seafloor environmental variables (Ruggedness on 11 pixels, large scale BPI on 25 pixels, small scale BPI on 3 pixels, Slope and Profile curvature) and three variables resulting from the hydrodynamic model: maximum temperature, mean and maximum current velocity.

\subsubsection{Model evaluation}

The AUC values of the ten replicates were all consistently high ( $>0.99)$ with a mean at 0.995 and a standard deviation of 0.002 . The measure of goodness of fit obtained with our mean model (test gain $=4.13$ ) means that the average likelihood of the presence samples is $\exp (4.13) \approx 62.2$ times higher than that of a random background pixel. This high AUC supported by a high test gain indicates that the model built for the study was powerful for predicting M. oculata habitat distribution in the Cassidaigne Canyon.

\subsubsection{Assessment of the importance of variables within the model}

The relative contributions of the environmental variables to the MaxEnt model show that seafloor ruggedness is the variable that contributed most to the model (contribution of Ruggedness on 11 pixels $=49.7 \%$ ), followed by maximum temperature (contribution of $\mathrm{T}$ $\max =29.6 \%$ ) and current velocity (contribution of mean velocity $=7.6 \%$ and contribution of maximum velocity $=7 \%$ ). The slope made the lowest contribution to the model, with only $5 \%$, and the contributions of the other three variables (large scale BPI on 25 pixels, small scale BPI on 3 pixels and profile curvature) amounted to around 1\% or less. Jackknife tests of the importance of variables helped to identify those with individual effects. The two most important single predictors were ruggedness (Ruggedness on 11 pixels) and the large scale Bathymetric Position Index (BPI on 25 pixels).

\subsubsection{Predicted distribution}

The potential distribution map was created using the $10^{\text {th }}$ percentile threshold $(0.66)$ to identify highly probable pixels for the $M$. oculata presence predicted by the model. The map shows the potential habitat of M. oculata distributed over a narrow area (Fig. 12).

The model identified five main areas of high habitat suitability for $M$. oculata distribution. Three of them are the known locations already sampled: Cassis-200, Cassis-500 and the Wall. However, the total area suitable for M. oculata at Cassis-200 and the Wall was predicted to expand towards the east of the Cassis-200 site downwards and towards the 
north and south of the Wall. The other two highly suitable areas identified (not yet visited) are located on a steep slope on the western side of the canyon, and on the top of a crest on the south-eastern side of the canyon. Small suitable areas are predicted in the canyon head, on the top of small topographic highs and on slopes.

Consistent with ecological knowledge on the species, the model predicts $M$. oculata will occur most frequently on irregular elevated topographic structures where current velocity is elevated.

When examining the distribution of scattered colonies already observed in the canyon (Fig. 1) but not considered in the model, it can be seen that many are located on the suitable areas predicted for M. oculata.

\section{Discussion}

\subsection{M. oculata spatial distribution}

\subsubsection{Cassis-500 site}

In 2013, when we visited the Cassis-500 site, the most obvious observations were the alignment of several large colonies of Callogorgia verticillata on the top of a ledge, large colonies of $M$. oculata growing out of the overhang, and very small ones growing downward and covering the ceiling of cavities under the overhang. These very small colonies seemed very fresh and young. Although no lasers could be used during the dive, we observed that these young colonies covering the ceilings of cavities were composed of around 40 polyps in length (Fig. 4D). Considering that 2 polyps are added to the extremities of a colony each year (linear growth) (Orejas et al., 2011), these small colonies must therefore be approximately 20 years old. This led us to estimate that they had recruited since approximately 1993. But we also know that this site is affected by red mud, but that its discharge has been reduced since 1988 because one of the two factories responsible had stopped production. This has probably led to the reduction in the concentration of red mud particles, leading to a more favorable environment for $M$. oculata recruitment and growth at this site, but only in protected areas such as cavities under overhangs.

On the contrary, large colonies of $C$. verticillata could be seen on the top of the ledge. These colonies do not seem to have been disturbed by the heavy load of red mud particles because no evidence of damage could be observed.

Sponges were also seen in abundance, although they were not sampled. They were essentially three species of glass sponges (Hexactinellidae): Tretodictyum cf. tubulosum, Farrea sp. and Oopsacas cf. minuta. The porifera Oopsacas minuta had been collected previously near the Cassidaigne canyon from an unusual littoral cave (called Trois Pépés) where the temperature is around $13^{\circ} \mathrm{C}$ all year round (Vacelet et al., 1994). Otherwise this species has also been collected and recorded by photos at bathyal depths in the Ligurian Sea (Bakran-Petricioli et al., 2007) One could speculate that if the Oopsacas species seen in abundance in the videos were 0 . minuta, then the Cassis-500 site could be the missing "stepping-stone" site between deep Ligurian areas and the nearby littoral cave (BakranPetricioli et al., 2007).

\subsubsection{Cassis-200 site}


The exploration of the Cassis-200 site in 2013 allowed visiting the eastern part of a small platform delineated by the $215 \mathrm{~m}$ isobath (Fig. 2) on the top of which large colonies of $M$. oculata were observed along with other species. This eastern part, further east from the continental shelf, did not support as many species from the shelf as on the western part visited previously (Bourcier and Zibrowius, 1973; Fabri et al., 2014).

\subsection{Environmental parameters driving M. oculata distribution}

\subsubsection{In situ water mass structure}

The water density envelope in which cold-water coral lives was suggested to play a role in the concentration of food particles and the lateral transport of larvae (Dullo et al., 2008). In the Northeast Atlantic the density envelope favoring the settlement of Lophelia pertusa, a scleractinian often living together with M. oculata, was estimated to be around $27.5 \mathrm{~kg} . \mathrm{m}^{-3}$ with a maximum of $27.65 \mathrm{~kg} . \mathrm{m}^{-3}$ (Dullo et al., 2008). Nevertheless, in the Whittard canyon they could be found in waters with a higher potential density up to $27.84 \mathrm{~kg} . \mathrm{m}^{-3}$ (Huvenne et al., 2011). This higher density envelope supporting cold-water corals in canyons has been assumed to be a consequence of downslope transport leading to the downward displacement of both food particles and larvae. The Cassis-200 site lies at the base of the AW layer, where the potential density anomaly is $>\sim 28.9 \mathrm{~kg} \cdot \mathrm{m}^{-3}$. The Cassis- 500 site lies in the salty layer of EIW where densities up to $\sim 29.08 \mathrm{~kg} . \mathrm{m}^{-3}$ were found at around $450 \mathrm{~m}$ depth in August 2014 (Fig. 6). Colonies of M. oculata and L. pertusa can also be found in Mediterranean canyons and on coral topped-mounds down to $\sim 1100 \mathrm{~m}$ depth at Santa Maria di Leuca (Freiwald et al., 2009; Mastrototaro et al., 2010), in the WMDW, where the potential density anomaly ranges from $\sim 29.0$ to $\sim 29.12 \mathrm{~kg} \cdot \mathrm{m}^{-3}$. This means that over the whole Mediterranean depth range (and including the seasonal variability) the density varies by only $\sim 0.2 \mathrm{~kg} . \mathrm{m}^{-3}$, while the density difference with the Atlantic is $\sim 1.0$ to $2.0 \mathrm{~kg} . \mathrm{m}^{-3}$. Therefore in the Mediterranean at least the density criterion may not be fully relevant. The in situ temperatures measured at $M$. oculata occurrences in the Cassidaigne canyon in August 2014 were in the lower part of the temperature range $\left(13.3^{\circ} \mathrm{C}\right.$ to $\left.13.9^{\circ} \mathrm{C}\right)$ described for the EIW (Alberola and Millot, 2003; Millot, 2013). During mild winters, in the absence of repeated intense and long-lasting Mistral events, the densification of surface AW water only occurs due to cooling, forming the Western Intermediate Water (WIW; detected by a temperature $<13.2^{\circ} \mathrm{C}$, (Vargas-Yáñez et al., 2012)) that sinks down to $\sim 200 \mathrm{~m}$, on the top of the EIW layer. Therefore at the interannual variability scale, the Cassis-200 site can end up bathing in this colder water coming from above. Nevertheless, experimental studies carried out in aquaria demonstrated that $M$. oculata presents higher respiration and calcification rates at $12^{\circ} \mathrm{C}$ than at lower temperatures $\left(9\right.$ and $6^{\circ} \mathrm{C}$ ) (Naumann et al., 2014). No experiment was carried out at $15^{\circ} \mathrm{C}$ which is the maximum temperature inventoried for M. oculata in the Atlantic Ocean (Keller and Os'kina, 2008).

\subsubsection{In situ turbidity and Suspended Sediment}

On the basis of turbidity measurements performed in the head of the Cassidaigne canyon, we could detect higher turbidity near the seafloor along the canyon axis than in the water column above $300 \mathrm{~m}$ depth. This confirms what we saw on the videos recorded near the bottom in this canyon (Fabri et al., 2014; Fontanier et al., 2012). We can assume that there is a continuous flow -albeit weak- at the bottom of the canyon with a higher concentration in particles than in the water above. This water mass was $200 \mathrm{~m}$ thick near the 
red mud pipeline and $100 \mathrm{~m}$ thick $8 \mathrm{~km}$ downstream, with turbidity tending to increase closer to the bottom. These observations pertain to a situation without Mistral, that is to say without upwelling. It is obvious that during Mistral events the 3D extent of the turbid layer will vary, but no elements are available so far to provide an adequate description.

The turbidity recorded from vertical profiles $100 \mathrm{~m}$ above the bottom ranged from 1 to $2.5 \mathrm{NTU}$, corresponding to $\mathrm{SSC}=0.6$ to $2 \mathrm{mg} / \mathrm{l}$ according to our calibration curve. We compared our calibration curve to that built for the Gulf of Lion ((Guillen et al., 2000) -figure 4) and found that our sensor gave the same range of NTU values for the same concentration, although we know that large particles were weighed but not detected optically because they tended to sink to the bottom of our container. We considered the interpretation of the turbidity data as SSC with caution, in line with the results of an experiment in which large particles were not measured as precisely as small particles (Ludwig and Hanes, 1990).

Time series recorded in the adjacent canyon (Planier canyon) $4 \mathrm{~m}$ above the bottom for 7 months in winter 2003-2004 showed an SSC around $0 \mathrm{mg} / \mathrm{l}$ and no peaks were observed even during storm events (Palanques et al., 2006; Ulses et al., 2008). Peaks could be observed for other canyons in the western part of the Gulf of Lion where SSC values increased up to $9.4 \mathrm{mg} / \mathrm{l}$ (Lacaze-Duthiers canyon) and to $68 \mathrm{mg} / \mathrm{l}$ (Cap de Creus canyon), events which only occur during dense shelf cascading in winter. We collected our data in summer (August 2014) and no storm events had occurred. Nevertheless we recorded higher SSC values than the baseline recorded in several canyons in the eastern part of the Gulf of Lion during winter periods with storm events. This led us to conclude that the high SSC turbid layer detected at the bottom of the Cassidaigne canyon (1) did not correspond to a natural nepheloid bottom layer (Bethoux et al., 2002), (2) is not due to a natural event like a storm (Palanques et al., 2006), and (3) is a direct consequence of the red mud present in this canyon for more than 45 years. This is confirmed by the samples collected on the bottom in 2010 and by the videos (Table 1; see figure 2 of Fontanier et al (2012)). These red mud particles have been shown to be re-suspended by currents of 0.2 to $0.4 \mathrm{~m} / \mathrm{s}$ (Alberola and Millot, 2003). Such strong currents have been shown to occur quite frequently in autumn (see section 4.2.4 hereafter).

\subsection{3 - Limits in the use of the bottom layer parameters resulting from the hydrodynamic model}

Water mass parameters resulting from the hydrodynamic model in the first $10 \mathrm{~m}$ above the bottom could not be considered for their absolute values - when compared with in situ values - for several reasons: the hydrodynamic modeling period (Autumn 2013) did not overlap the CTD transect period (August 2014), the computing time was excessive for modeling a full year and no consistent annual boundary forcing was available at the time of this study. An annual to interannual modeling experiment is required to refine the assessment of the hydrology and currents in the coral habitat. Additional time series of CTD and current measurements should be collected to validate the hydrodynamic models and to provide an adequate description of the variability along the canyon axis at the event scale of upwelling, downwelling, maximum currents, as well as at the seasonal scale of WIW formation and isopycnal slope variation, up to decadal variability and trends.

Nevertheless the order of magnitude of surface hydrology and currents was validated and the relative information resulting from the hydrodynamic model can be used to quantify the relationships between environmental variables at $M$. oculata presence points. 


\subsubsection{Variables used in the MaxEnt model}

Terrain irregularities, steep slopes and, to a more limited extent, topographic highs were identified as playing a role in $M$. oculata distribution in the Cassidaigne canyon. Previous studies have linked these terrain parameters to seabed features like continental slopes, large seamounts (Tittensor et al., 2009), carbonate mounds (Guinan et al., 2009) and sediment waves (Dolan et al., 2008) on which cold-water corals have been found in other areas.

Terrain irregularities (on an 11-pixel window size) and topographic highs (on a 25-pixel window size) at a spatial scale of 100-250 $\mathrm{m}$ are the two variables identified in the jackknife tests as contributing most to $M$. oculata distribution. Nevertheless, the topographic highs (on 25 pixels) only contribute $1.1 \%$ to the final MaxEnt model. They probably provide the same information and both encode for large scale topographic features.

The three environmental variables from the hydrodynamic model were all identified as influencing $M$. oculata in the Cassidaigne canyon, with a major role being played by water temperature in addition to current velocities (maximum and mean values). Coral colonies were clearly located where maximum current velocities were computed by the hydrodynamic model CASCANS (Fig. 10C).

\subsection{Predictive suitable habitat}

The default prevalence used in the model was set to 0.7 (instead of the 0.5 default value used if nothing is known about the species distribution) according to the knowledge of the species distribution we had before sampling the area.

In our study, the occurrence data were not equally distributed over the area, they were mainly located at three main sites (Cassis-200, Cassis500 and Wall) on the western part of the canyon. Nevertheless, the results obtained with the MaxEnt model are consistent with the knowledge we now have of $M$. oculata environmental parameter preferences. The MaxEnt model built for this study confirmed the strong relationships between $M$. oculata distribution, bathymetric derived data (irregularities, steep slopes and topographic highs), hydrology (water temperature) and hydrodynamics (maximum and mean values of current velocities). The suitable habitat map produced by the model highlights pixels of probable occurrence of $M$. oculata located on very sharp crests in the canyon (topographic highs), which is also very rugged. These areas are mainly located where the presence of the species is already known in the head of the canyon, which suggests that the species had already settled on every area fitting the corresponding predictive variables. However, on the western and eastern side at the exit of the canyon, two as yet unexplored areas have been identified as suitable for $M$. oculata and ground truthing could be oriented to these areas in the future. This is especially interesting since these areas are located where current velocity values are high according to the hydrodynamic model outputs (Fig. 10C).

We already know that several areas predicted as suitable for $M$. oculata are occupied by scattered colonies. All the predicted areas will have to be fully explored before any conclusion can be drawn. Nevertheless if ground truthing confirms in the future that predicted areas do not host colonies of $M$. oculata, then it can be imagined that either they are not optimal habitats (which means factors are missing in our model), or they may be subject to heavy pressure. As the Cassidaigne canyon has received discharges of red mud since 1967, this anthropogenic pressure is the first to have been identified as preventing $M$. oculata from expanding on areas suitable for its settlement (Fabri et al., 2014), obviously near the head of the canyon where the residues are expelled. Nevertheless, at the exit of the 
canyon where two areas are predicted to be suitable for coral colonies, fishing activity, global change or natural factors not captured by the model could also be the reason for their absence (if any). Identification of the pressure following ground truthing will be a real challenge, especially since monitoring and recovering seafloor integrity is one of the objectives of the Marine Strategy Directive (MSFD) for 2020.

\section{Conclusion}

Colonies of M. oculata observed at the Cassis-500 site in Cassidaigne canyon were healthy and young, growing downward under an overhang. They appeared spread out in an environment with a high suspended sediment concentration, salinity and water density. It is suggested that their expansion is linked to the reduction of the red mud discharge in the canyon since 1988, even though the sediment remains highly re-suspendable. We could observe the recovery of this ecosystem only at the Cassis-500 site which is sheltered from the direct flux of red mud. The accompanying species at this site are limited and different from the species observed at the Cassis-200 site. This difference may be caused by the difference in depth or in configuration (overhang versus rocky outcrop) between both sites, or because the environment harbors such extreme conditions under the red mud flux, or its resuspension at $500 \mathrm{~m}$ depth limits the diversity of benthic fauna.

The habitat suitability model built with MaxEnt identified seafloor locations harboring irregularities, topographic highs and steep slopes that favor $M$. oculata settlements. Concerning environmental variables resulting from the hydrodynamic model, temperature and high current velocities were identified as explanatory factors of the distribution of $M$. oculata. High resolution hydrodynamic model predictions over a whole year would make it possible to calculate other variables to better explain $M$. oculata distribution, such as the frequency and duration of high-velocity current episodes, and the amplitude in temperature, salinity and water density variations at the location colonized. Data discriminating hard bottoms from soft bottoms such as backscatter data could also help to better predict suitable areas. Multiparametric time series along the water column are needed to provide an adequate description of the hydrodynamic environment, and feed spatial-scale refined models.

This study is an example of how a limited number of areas can be identified in order to focus monitoring, and is an approach for encouraging the management of sensitive ecosystems in deep seas.

\section{Acknowledgements}

This paper was written in the framework of the Marine Strategy Directive (MSFD). The Habitat Suitability model study was part of a post-doctoral grant funded by the "Agence de l'Eau Rhône Méditerranée \& Corse" under Convention Number 20150348 . We are grateful to all the participants and the P.I. of the ESSROV 2010 (http://dx.doi.org/10.17600/10030090), ESSNAUT 2013 (http://dx.doi.org/10.17600/13010060) and BATHYCOR1 2014 (http://dx.doi.org/10.17600/14006300) cruises, and especially to P. Triger for the Nautile dive in the Cassidaigne canyon. We also thank H. Biscaye, B. Loubrieu, O. Soubigou, G. Clodic, ME. Bouhier and G. Rougier for their help in the use of the different processing software applications. The authors thank F. Zuberer for providing the T-MedNEt Cassidaigne time- 
series and R. Capelli for the matlab script generating ellipses. The setting of the hydrodynamic model using AGRIF benefited from the help of P. Garreau, S. Petton, S. Theetten, F. Dumas and V. Garnier. Furthermore, we are indebted to Keith Hodson (http://www.accent-europe.fr) for correcting the English. The authors also thank the reviewers for their helpful comments aimed at improving the manuscript.

\section{References}

Alberola, C., Millot, C., 2003. Circulation in the French Mediterranean coastal zone near Marseilles: the influence of wind and the Northern Current, Continental Shelf Research 23, 6, 587-610, 10.1016/s0278-4343(03)000025.

Bakran-Petricioli, T., Vacelet, J., Zibrowius, H., Petricioli, D., Chevaldonne, P., Rada, T., 2007. New data on the distribution of the 'deep-sea' sponges Asbestopluma hypogea and Oopsacas minuta in the Mediterranean Sea, Marine Ecology-an Evolutionary Perspective 28, 10-23.

Bethoux, J.P., de Madron, X.D., Nyffeler, F., Tailliez, D., 2002. Deep water in the western Mediterranean: peculiar 1999 and 2000 characteristics, shelf formation hypothesis, variability since 1970 and geochemical inferences, Journal of Marine Systems 33, 117-131, Pii s0924-7963(02)00055-6 10.1016/s09247963(02)00055-6.

Bourcier, M., Zibrowius, H., 1973. Les "boues rouges" déversées dans le canyon de la Cassidaigne : Observations en soucoupe plongeante SP350 (Juin 1971) et résultats de draguages, Tethys 4, 4, 811-842.

Dauvin, J.C., 2010. Towards an impact assessment of bauxite red mud waste on the knowledge of the structure and functions of bathyal ecosystems: The example of the Cassidaigne canyon (north-western Mediterranean Sea), Marine Pollution Bulletin 60, 2, 197-206, 10.1016/j.marpolbul.2009.09.026.

Davies, A.J., Duineveld, G.C.A., Lavaleye, M.S.S., Bergman, M.J.N., van Haren, H., Roberts, J.M., 2009. Downwelling and deep-water bottom currents as food supply mechanisms to the cold-water coral Lophelia pertusa (Scleractinia) at the Mingulay Reef complex, Limnology and Oceanography 54, 2, 620-629, 10.4319/lo.2009.54.2.0620.

Davies, A.J., Guinotte, J.M., 2011. Global Habitat Suitability for Framework-Forming Cold-Water Corals, Plos One 6, 4, e18483

10.1371/journal.pone.0018483.

Debreu, L., Vouland, C., Blayo, E., 2008. AGRIF: Adaptive grid refinement in Fortran, Computers \& Geosciences 34, 1, 8-13, 10.1016/j.cageo.2007.01.009.

Dolan, M.F.J., Grehan, A.J., Guinan, J.C., Brown, C., 2008. Modelling the local distribution of cold-water corals in relation to bathymetric variables: Adding spatial context to deep-sea video data, Deep Sea Research Part I: Oceanographic Research Papers 55, 11, 1564-1579.

Dullo, W.-C., Floegel, S., Rueggeberg, A., 2008. Cold-water coral growth in relation to the hydrography of the Celtic and Nordic European continental margin, Mar. Ecol. Prog. Ser. 371, 165-176, 10.3354/meps07623.

Elith, J., Graham, C.H., Anderson, R.P., Dudik, M., Ferrier, S., Guisan, A., Hijmans, R.J., Huettmann, F., Leathwick, J.R., Lehmann, A., Li, J., Lohmann, L.G., Loiselle, B.A., Manion, G., Moritz, C., Nakamura, M., Nakazawa, Y., Overton, J.M., Peterson, A.T., Phillips, S.J., Richardson, K., Scachetti-Pereira, R., Schapire, R.E., Soberon, J., Williams, S., Wisz, M.S., Zimmermann, N.E., 2006. Novel methods improve prediction of species' distributions from occurrence data, Ecography 29, 2, 129-151, 10.1111/j.2006.0906-7590.04596.x.

Elith, J., Leathwick, J.R., 2009. Species Distribution Models: Ecological Explanation and Prediction Across Space and Time, Annual Review of Ecology, Evolution, and Systematics 40, 1, 677-697, doi:10.1146/annurev.ecolsys.110308.120159.

Elith, J., Phillips, S.J., Hastie, T., Dudík, M., Chee, Y.E., Yates, C.J., 2011. A statistical explanation of MaxEnt for ecologists, Diversity and Distributions 17, 1, 43-57, 10.1111/j.1472-4642.2010.00725.x.

European Parliament, 2008. Directive (2008/56/EC) establishing a framework for community action in the field of marine environmental policy (Marine Strategy Framework Directive), Off. J. Eur. Union (www.eurlex.europa.eu), pp. 1-22.

Fabri, M.C., 2015. Bathymétrie : MNT du canyon de Cassidaigne (ESSROV 2010, résolution 10m). Ifremer centre de Méditerranée, http://dx.doi.org/10.12770/af034154-33da-480f-aa78-817eac6563b7.

Fabri, M.C., Pedel, L., Beuck, L., Galgani, F., Hebbeln, D., Freiwald, A., 2014. Megafauna of vulnerable marine ecosystems in French mediterranean submarine canyons: Spatial distribution and anthropogenic impacts, Deep-Sea Research Part Ii-Topical Studies in Oceanography 104, 184-207, 10.1016/j.dsr2.2013.06.016.

Fontanier, C., Biscara, L., Mamo, B., Delord, E., 2014. Deep-sea benthic foraminifera in an area around the Cassidaigne Canyon (NW Mediterranean) affected by bauxite discharges, Marine Biodiversity 44, 4, 10.1007/s12526-014-0281-9. 
Fontanier, C., Fabri, M.C., Buscail, R., Biscara, L., Koho, K., Reichart, G.J., Cossa, D., Galaup, S., Chabaud, G., Pigot, L., 2012. Deep-sea foraminifera from the Cassidaigne Canyon (NW Mediterranean): Assessing the environmental impact of bauxite red mud disposal, Marine Pollution Bulletin 64, 9, 1895-1910, 10.1016/j.marpolbul.2012.06.016.

Freiwald, A., Beuck, L., Rüggeberg, A., Taviani, M., Hebbeln, D., 2009. The white coral community in the Central Mediterranean Sea revealed by ROV Surveys, Oceanography 22, 1, 58-74.

Freiwald, A., Fossa, J.H., Grehan, A., Koslow, J.A., Roberts, J.M., 2004. Cold-water Coral Reefs: Out of Sight - No Longer Out of Mind. UNEP-WCMC,Cambridge, UK.

Garnier, C., Pairaud, I., Nicolle, A., Alekseenko, E., Baklouti, M., Thouvenin, B., Lecornu, F., Garreau, P., 2014. MENOR: a high-resolution $(1.2 \mathrm{~km})$ modeling of the North-Western Mediterranean Sea routinely run by the PREVIMER operational forecast system., Mercator Ocean - Quarterly Newsletter, pp. 69-75.

Guillen, J., Palanques, A., Puig, P., De Madron, X.D., Nyffeler, F., 2000. Field calibration of optical sensors for measuring suspended sediment concentration in the western Mediterranean, Scientia Marina 64, 4, 427-435.

Guinan, J., Brown, C., Dolan, M.F.J., Grehan, A.J., 2009. Ecological niche modelling of the distribution of coldwater coral habitat using underwater remote sensing data, Ecological Informatics 4, 2, 83-92, 10.1016/j.ecoinf.2009.01.004.

Guisan, A., Zimmermann, N.E., 2000. Predictive habitat distribution models in ecology, Ecological Modelling 135, 2-3, 147-186, http://dx.doi.org/10.1016/S0304-3800(00)00354-9.

Howell, K.L., Holt, R., Endrino, I.P., Stewart, H., 2011. When the species is also a habitat: Comparing the predictively modelled distributions of Lophelia pertusa and the reef habitat it forms, Biological Conservation 144, 11, 2656-2665, 10.1016/j.biocon.2011.07.025.

Huvenne, V.A.I., Tyler, P.A., Masson, D.G., Fisher, E.H., Hauton, C., Huehnerbach, V., Le Bas, T.P., Wolff, G.A., 2011. A Picture on the wall: Innovative mapping reveals cold-water coral refuge in submarine canyon, Plos One 6, 12, e28755, e28755 10.1371/journal.pone.0028755.

Keller, N.B., Os'kina, N.S., 2008. Habitat temperature ranges of azooxantellate scleractinian corals in the World Ocean, Oceanology 48, 1, 77-84, 10.1134/s0001437008010098.

Lazure, P., Dumas, F., 2008. An external-internal mode coupling for a 3D hydrodynamical model for applications at regional scale (MARS), Advances in Water Resources 31, 2, 233-250, 10.1016/j.advwatres.2007.06.010.

Lobo, J.M., Jimenez-Valverde, A., Real, R., 2008. AUC: a misleading measure of the performance of predictive distribution models, Global Ecology and Biogeography 17, 2, 145-151, 10.1111/j.1466-8238.2007.00358.x.

Ludwig, K.A., Hanes, D.M., 1990. A laboratory evaluation of optical backscatterance suspended-solids sensors exposed to sand-mud mixtures, Marine Geology 94, 1-2, 173-179, 10.1016/0025-3227(90)90111-v.

Mastrototaro, F., D'Onghia, G., Corriero, G., Matarrese, A., Maiorano, P., Panetta, P., Gherardi, M., Longo, C., Rosso, A., Sciuto, F., Sanfilippo, R., Gravili, C., Boero, F., Taviani, M., Tursi, A., 2010. Biodiversity of the white coral bank off Cape Santa Maria di Leuca (Mediterranean Sea): An update, Deep Sea Research Part II 57, 5-6, 412-430.

Merow, C., Smith, M.J., Silander, J.A., 2013. A practical guide to MaxEnt for modeling species' distributions: what it does, and why inputs and settings matter, Ecography 36, 10, 1058-1069, 10.1111/j.1600-0587.2013.07872.x.

Millot, C., 1990. The Gulf of Lions' hydrodynamics, Continental Shelf Research 10, 9-11, 885-894.

Millot, C., 2013. Levantine Intermediate Water characteristics: an astounding general misunderstanding!, Scientia Marina 77, 2, 217-232, 10.3989/scimar.03518.13A.

Millot, C., Taupier-Letage, I., 2005. Circulation in the Mediterranean Sea.[Heidelberg (Ed.)] Handbook of Environmental Chemistry, $n^{\circ} 5$ : Water pollution, Part K, pp. 29-66, Springer-Verlag, Berlin, http://dx.doi.org/10.1007/b107143.

Mohn, C., Rengstorf, A., White, M., Duineveld, G., Mienis, F., Soetaert, K., Grehan, A., 2014. Linking benthic hydrodynamics and cold-water coral occurrences: A high-resolution model study at three cold-water coral provinces in the NE Atlantic, Progress in Oceanography 122, 92-104, 10.1016/j.pocean.2013.12.003.

Naumann, M.S., Orejas, C., Ferrier-Pagès, C., 2014. Species-specific physiological response by the cold-water corals Lophelia pertusa and Madrepora oculata to variations within their natural temperature range, Deep Sea Research Part II: Topical Studies in Oceanography 99, 0, 36-41, http://dx.doi.org/10.1016/j.dsr2.2013.05.025.

Orejas, C., Ferrier-Pages, C., Reynaud, S., Gori, A., Beraud, E., Tsounis, G., Allemand, D., Gili, J.M., 2011. Longterm growth rates of four Mediterranean cold-water coral species maintained in aquaria, Marine EcologyProgress Series 429, 57-65, 10.3354/meps09104.

Pairaud, I.L., Bensoussan, N., Garreau, P., Faure, V., Garrabou, J., 2014. Impacts of climate change on coastal benthic ecosystems: assessing the current risk of mortality outbreaks associated with thermal stress in NW Mediterranean coastal areas, Ocean Dynamics 64, 1, 103-115, 10.1007/s10236-013-0661-x.

Pairaud, I.L., Gatti, J., Bensoussan, N., Verney, R., Garreau, P., 2011. Hydrology and circulation in a coastal area off Marseille: Validation of a nested 3D model with observations, Journal of Marine Systems 88, 1, 20-33, 10.1016/j.jmarsys.2011.02.010. 
Palanques, A., Durrieu de Madron, X., Puig, P., Fabres, J., Guillen, J., Calafat, A., Canals, M., Heussner, S., Bonnin, J., 2006. Suspended sediment fluxes and transport processes in the Gulf of Lions submarine canyons. The role of storms and dense water cascading, Marine Geology 234, 1-4, 43-61, 10.1016/j.margeo.2006.09.002.

Pearson, R.G., Raxworthy, C.J., Nakamura, M., Peterson, A.T., 2007. Predicting species distributions from small numbers of occurrence records: a test case using cryptic geckos in Madagascar, Journal of Biogeography 34, 1, 102-117, 10.1111/j.1365-2699.2006.01594.x.

Phillips, S.J., Anderson, R.P., Schapire, R.E., 2006. Maximum entropy modeling of species geographic distributions, Ecological Modelling 190, 3-4, 231-259, 10.1016/j.ecolmodel.2005.03.026.

Phillips, S.J., Dud, M., \#237, Schapire, R.E., 2004. A maximum entropy approach to species distribution modeling, Proceedings of the twenty-first international conference on Machine learning. ACM,Banff, Alberta, Canada, p. 83, 10.1145/1015330.1015412.

Phillips, S.J., Dudik, M., 2008. Modeling of species distributions with Maxent: new extensions and a comprehensive evaluation, Ecography 31, 2, 161-175, 10.1111/j.0906-7590.2008.5203.x.

Reiswig, H.M., 2014. Six new species of glass sponges (Porifera: Hexactinellida) from the north-eastern Pacific Ocean, Journal of the Marine Biological Association of the United Kingdom 94, 2, 267-284, 10.1017/s0025315413000210.

Rengstorf, A.M., Grehan, A., Yesson, C., Brown, C., 2012. Towards High-Resolution Habitat Suitability Modeling of Vulnerable Marine Ecosystems in the Deep-Sea: Resolving Terrain Attribute Dependencies, Marine Geodesy 35, 4, 343-361, 10.1080/01490419.2012.699020.

Rengstorf, A.M., Mohn, C., Brown, C., Wisz, M.S., Grehan, A.J., 2014. Predicting the distribution of deep-sea vulnerable marine ecosystems using high-resolution data: Considerations and novel approaches, Deep-Sea Research Part I-Oceanographic Research Papers 93, 72-82, 10.1016/j.dsr.2014.07.007.

Reveillaud, J., Allewaert, C., Pérez, T., Vacelet, J., Banaigs, B., Vanreusel, A., 2012. Relevance of an integrative approach for taxonomic revision in sponge taxa: case study of the shallow-water Atlanto-Mediterranean Hexadella species (Porifera : Ianthellidae : Verongida), Invertebrate Systematics 26, 3, 230-248, http://dx.doi.org/10.1071/IS11044.

Ross, R.E., Howell, K.L., 2013. Use of predictive habitat modelling to assess the distribution and extent of the current protection of 'listed' deep-sea habitats, Diversity and Distributions 19, 4, 433-445, 10.1111/ddi.12010.

Tassy, A., Fournier, F., Munch, P., Borgomano, J., Thinon, I., Fabri, M.C., Rabineau, M., Arfib, B., Begot, J., Beslier, M.-O., Cornée, J.-J., Fournillon, A., Gorini, C., Guennoc, P., Léonide, P., Oudet, J., Paquet, F., Sage, F., Toullec, R., 2014. Discovery of Messinian canyons and new seismic stratigraphic model, offshore Provence (SE France): Implication for the hydrographic network reconstruction, Marine and Petroleum Geology 57, 25-50, http://dx.doi.org/10.1016/j.marpetgeo.2014.05.001.

Tittensor, D.P., Baco, A.R., Brewin, P.E., Clark, M.R., Consalvey, M., Hall-Spencer, J., Rowden, A.A., Schlacher, T., Stocks, K.I., Rogers, A.D., 2009. Predicting global habitat suitability for stony corals on seamounts, Journal of Biogeography 36, 6, 1111-1128, 10.1111/j.1365-2699.2008.02062.x.

Tittensor, D.P., Baco, A.R., Hall-Spencer, J.M., Orr, J.C., Rogers, A.D., 2010. Seamounts as refugia from ocean acidification for cold-water stony corals, Marine Ecology 31, 212-225, 10.1111/j.1439-0485.2010.00393.x.

Ulses, C., Estournel, C., Durrieu de Madron, X., Palanques, A., 2008. Suspended sediment transport in the Gulf of Lions (NW Mediterranean): Impact of extreme storms and floods, Continental Shelf Research 28, 15, 2048 2070, http://dx.doi.org/10.1016/j.csr.2008.01.015.

Vacelet, J., Bouryesnault, N., Harmelin, J.G., 1994. Hexactinellid cave, a unique deep-sea habitat in the scuba zone, Deep-Sea Research Part I-Oceanographic Research Papers 41, 7, 965-973.

Van Soest, R., 2015. Tretodictyum tubulosum Schulze, 1886. World Porifera database. Accessed through: World Register of Marine Species at http://www.marinespecies.org/aphia.php?p=taxdetails\&id=134397 on 2015-11-09.

Vargas-Yáñez, M., Zunino, P., Schroeder, K., López-Jurado, J.L., Plaza, F., Serra, M., Castro, C., García-Martínez, M.C., Moya, F., Salat, J., 2012. Extreme Western Intermediate Water formation in winter 2010, Journal of Marine Systems 105-108, 52-59, http://dx.doi.org/10.1016/j.jmarsys.2012.05.010.

Vierod, A.D.T., Guinotte, J.M., Davies, A.J., 2014. Predicting the distribution of vulnerable marine ecosystems in the deep sea using presence-background models, Deep Sea Research Part II: Topical Studies in Oceanography 99, 0, 6-18, http://dx.doi.org/10.1016/j.dsr2.2013.06.010.

Wilson, M.F.J., O’Connell, B., Brown, C., Guinan, J.C., Grehan, A.J., 2007. Multiscale Terrain Analysis of Multibeam Bathymetry Data for Habitat Mapping on the Continental Slope, Marine Geodesy 30, 1-2, 3-35, 10.1080/01490410701295962.

Wisz, M.S., Hijmans, R.J., Li, J., Peterson, A.T., Graham, C.H., Guisan, A., Group, N.P.S.D.W., 2008. Effects of sample size on the performance of species distribution models, Diversity and Distributions 14, 5, 763-773, 10.1111/j.1472-4642.2008.00482.x.

Wright, D.J., Lundblad, E.R., Larkin, E.M., Rinehart, R.W., Murphy, J., Cary-Kothera, L., Draganov, K., 2005. ArcGIS Benthic Terrain Modeler. 
Yesson, C., Taylor, M.L., Tittensor, D.P., Davies, A.J., Guinotte, J., Baco, A., Black, J., Hall-Spencer, J.M., Rogers, A.D., 2012. Global habitat suitability of cold-water octocorals, Journal of Biogeography 39, 7, 1278-1292, 10.1111/j.1365-2699.2011.02681.x.

Fig. 1. Location of Cassidaigne Canyon, near Marseille, France and bathymetric map established during the ESSROV2010 cruise (10 m resolution) (Fabri, 2015). The black line represents the pipe discharging red mud into the canyon since 1967.

Fig. 2: Bathymetric map established during the BATHYCOR1 cruise with AUV Idef'X (2014) and Nautile navigation track (in red) along dive 1852-10 (ESSNAUT 2013). A: Bathymetric map of the Cassidaigne canyon head at $2 \mathrm{~m}$ resolution. B: Location of $M$. oculata (in green) at the Cassis- 500 site observed during dive1852-10 (ESSNAUT 2013). C: Location of M. oculata (in green) at the Cassis-200 site observed during dive1852-10 (ESSNAUT 2013).

Fig. 3: Bathymetry of the hydrodynamic model configurations and nesting strategy: MENOR forcing CASCANL, 2-way nesting between CASCANL and CASCANS using AGRIF.

Fig. 4: Images of the Cassis-500 site recorded during the ESSNAUT 2013 dive 1852-10. A- Large colonies of Callogorgia verticillata lining the top of the ledge. B- An example of a large $M$. oculata colony with its dead basal part covered with red mud. C- Small colonies of M. oculata covering the ceiling of a natural cave and growing downwards. D- Small colonies of $M$. oculata exhibiting very thin and long branches. E- An assemblage of three sponges Tretodictyum cf tubulosum (Tt), Oopsacas cf. minuta $(\mathrm{Om})$ and Hexadella cf. crypta $(\mathrm{Hc})$ settled on a skeleton covered with red mud. F- The glass sponges Tretodictyum cf tubulosum (Tt) and Farrea sp. (Fsp) and the crustacean Munida sp. (Msp). GAn assemblage of cnidarians with Antipathes cf. dichotoma (Ad), Acanthogorgia hirsuta (Ah) and Plexauridae (P). H-Solitary Desmophyllum dianthus (Dd) together with another non-identified very thin solitary scleractinian (Sni).

Fig. 5. Images of Cassis-200 recorded in 2010 (ESSROV) and 2013 (ESSNAUT). (A) Distribution of $M$. oculata colonies on one side of a rocky outcrop (ESSROV 2010); (B) Overview of M. oculata colonies facing the dominant current and the echinoderm Cidaris cidaris (Cc) (ESSNAUT 2013); (C) Echinus melo $(\mathrm{Em})$, Corallium rubrum $(\mathrm{Cr})$, Leiopathes glaberria $(\mathrm{Lg})$, Eunicelle sp. and a wide diversity of sponges living together with M. oculata; (D) Large colonies of M. oculata (ESSNAUT 2013).

Fig. 6: Potential temperature versus practical salinity (theta-S) diagram including a zoom (top right) obtained from CTD profiles selected along the canyon axis from the BATHYCOR1 transect (CTD A to J; see Fig. 1). Superimposed lines show potential density anomalies as isopycnals $\left(\mathrm{kg} \cdot \mathrm{m}^{-3}\right)$. Water masses are identified on the diagram: AW (Atlantic Water), EIW Eastern Intermediate Water; WMDW: Western Mediterranean Deep Water.

Fig. 7: Turbidity section performed along the Cassidaigne canyon axis on the $23^{\text {th }}$ August 2014 during the BATHYCOR1 cruise. Black dots represent the bottom depth at each profile station.

Fig. 8. Box plots of five independent variables derived from the bathymetry on the total area (Total) and at the presence points of M. oculata colonies (M.o). 
Fig. 9. Comparison of the temperature recorded at the Cassidaigne station from T-MedNet (top) and the interpolated CASCANL and CASCANS modelled temperature (bottom).

Fig. 10. Outputs of the CASCANS model configuration for September to December 2013. Mean currents and variance ellipses (size reduced by a factor of 5), every 20 model grid points, $A$ : in the upper layer between 70-100 m depth; B: in the $10 \mathrm{~m}$ above the bottom. The variance ellipses show the variability of one standard deviation of the vectors about their mean. The ellipse plot gives the variability of both the magnitude and direction of vectors. Note that the ellipse is not necessarily oriented along the vector direction, but rotated as a function of the principal components of the variability. C: Maximum currents above the bottom (or at the first sigma level in the deepest area). Isobaths are plotted every $100 \mathrm{~m}$ down to $1500 \mathrm{~m}$.

Fig. 11: Box plots of three variables resulting from the hydrodynamic model for Autumn 2013 over the total area (Total) and at the presence points of M. oculata colonies (M.o).

Fig. 12. Map displaying the probability of the presence of $M$. oculata in the Cassidaigne Canyon generated with a model built using MaxEnt. Only areas identified as $M$. oculata presence above the $10^{\text {th }}$ percentile threshold $(0.66-1)$ are colored in red.

\section{Table 1}

List of expeditions, dives and type of data collected and used to describe the Cassidaigne canyon environment in this study.

\section{Table 2}

List of 13 stations on which vertical profiles (24 CTD and 10 turbidity) were collected during the BATHYCOR1 cruise in 2014. 


\begin{tabular}{|c|c|c|c|c|c|c|c|}
\hline Expeditions & $\begin{array}{c}\text { Research } \\
\text { Vessel \& } \\
\text { Submersible } \\
\end{array}$ & Data Type \&Equipment & Site, location & $\begin{array}{l}\text { Dive } \\
\mathrm{nb}\end{array}$ & $\begin{array}{c}\text { Total dive } \\
\text { distance } \\
(\mathrm{m})\end{array}$ & $\begin{array}{c}\text { Depth } \\
\text { range } \\
(\mathrm{m})\end{array}$ & Reference \\
\hline \multirow{2}{*}{$\begin{array}{l}\text { Agence des Aires Marines } \\
\text { Protégées } \\
\text { MEDSEACAN } 2009 \text { Expedition }\end{array}$} & Comex & & & & & & \\
\hline & $\begin{array}{c}\text { Super Achille } \\
\text { ROV }\end{array}$ & Video & Cassis-200 & P1 & 2179 & $205-215$ & $\begin{array}{c}\text { Fabri et al, } \\
2014\end{array}$ \\
\hline \multirow[t]{2}{*}{$\begin{array}{c}\text { Marum } \\
\text { MARUM } 2009 \text { Expedition }\end{array}$} & $\begin{array}{c}\text { Comex } \\
\text { R/V Minibex }\end{array}$ & & & & & & \\
\hline & $\begin{array}{c}\text { Super Achille } \\
\text { ROV }\end{array}$ & Video & $\begin{array}{l}\text { Cassis-200 } \\
\text { isolated colonies } \\
\text { isolated colonies } \\
\text { isolated colonies }\end{array}$ & $\begin{array}{l}\text { D2 } \\
\text { D5 } \\
\text { D7 } \\
\text { D8 }\end{array}$ & $\begin{array}{c}2745 \\
1561 \\
2101 \\
307\end{array}$ & $\begin{array}{l}184-240 \\
198-370 \\
243-465 \\
187-237\end{array}$ & $\begin{array}{c}\text { Fabri et al, } \\
2014\end{array}$ \\
\hline $\begin{array}{c}\text { Marum } \\
\text { MARUM } 2009 \text { Expedition }\end{array}$ & $\begin{array}{c}\text { Comex } \\
\text { R/V Minibex }\end{array}$ & & & & & & \\
\hline \multirow[t]{2}{*}{$\begin{array}{c}\text { Ifremer } \\
\text { ESSROV } 2010 \text { Expedition } \\
\text { dx.doi.org/10.17600/10030090 }\end{array}$} & $\begin{array}{l}\text { Ifremer } \\
\text { RN Pourquoi } \\
\text { pas? }\end{array}$ & $\begin{array}{c}\text { Bathymetry } \\
\text { Hull-mounted } \\
\text { Reson Seabat } 7150 \\
(24 \mathrm{kHz}) \\
\text { http://doi.org/10.12770/af034154- } \\
\text { 33da-480f-aa78-817eac6563b7 }\end{array}$ & $\begin{array}{l}\text { Cassidaigne } \\
\text { Canyon }\end{array}$ & & & & This study \\
\hline & $\begin{array}{c}\text { Ifremer } \\
\text { Victor } 6000 \\
\text { ROV }\end{array}$ & HD video & $\begin{array}{l}\text { isolated colonies } \\
\text { Cassis-200 }\end{array}$ & $\begin{array}{l}397-01 \\
401-05\end{array}$ & $\begin{array}{c}998 \\
4248\end{array}$ & $\begin{array}{c}251-400 \\
60-284\end{array}$ & $\begin{array}{l}\text { Fabri et al, } \\
2014\end{array}$ \\
\hline \multirow{2}{*}{$\begin{array}{c}\text { Ifremer } \\
\text { ESSNAUT } 2013 \text { Expedition } \\
\text { dx.doi.org/10.17600/10030090 }\end{array}$} & $\begin{array}{c}\text { Ifremer } \\
\text { R/V L'Atalante }\end{array}$ & & & & & & \\
\hline & $\begin{array}{c}\text { Nautile } \\
\text { Manned } \\
\text { Submersible }\end{array}$ & HD video & $\begin{array}{l}\text { Cassis-200 \& } \\
\text { Cassis-500 }\end{array}$ & $1852-10$ & 1853 & $188-562$ & This study \\
\hline \multirow[t]{3}{*}{$\begin{array}{c}\text { Ifremer } \\
\text { BATHYCOR1 2014 } \\
\text { dx.doi.org/10.17600/14006300 }\end{array}$} & $\begin{array}{c}\text { Ifremer } \\
\text { R/V L'Europe }\end{array}$ & $\begin{array}{l}10 \text { Turbidity profiles } \\
\text { NKE STBD } 1200\end{array}$ & $\begin{array}{c}\text { Cassidaigne } \\
\text { Canyon } \\
\text { axis and flanks }\end{array}$ & & & & This study \\
\hline & & $\begin{array}{c}24 \text { CTD profiles } \\
\text { SeaBird SBE } 19 \text { PlusV2 }\end{array}$ & $\begin{array}{l}\text { Cassidaigne } \\
\text { Canyon } \\
\text { axis and flanks }\end{array}$ & & & & This study \\
\hline & $\begin{array}{c}\text { Idef'X } \\
\text { AUV }\end{array}$ & $\begin{array}{l}\text { Kongsberg } \\
\text { EM } 2040 \\
(200 \mathrm{kHz})\end{array}$ & $\begin{array}{l}\text { Cassis-200 } \\
\text { Cassis-200 } \\
\text { Cassis-200 } \\
\text { Cassis-200 } \\
\text { Cassis-200 }\end{array}$ & $\begin{array}{l}175-08 \\
176-09 \\
177-10 \\
178-11 \\
179-12 \\
\end{array}$ & & & This study \\
\hline
\end{tabular}


Table 2

List of 13 stations on which vertical profiles (24 CTD and 10 turbidity) were collected during the BATHYCOR1 cruise in 2014.

\begin{tabular}{|c|c|c|c|c|c|c|c|}
\hline Station & Latitude & Longitude & CTD & $\begin{array}{c}\text { Bottom } \\
\text { Depth (m) }\end{array}$ & DATE & TIME & $\begin{array}{c}\text { STBD } \\
\text { Max } \\
\text { Depth } \\
\text { (m) }\end{array}$ \\
\hline A & N 433,8171 & E 527,7867 & CTD 11 & 1134 & $23 / 08 / 2014$ & $06: 40: 45$ & 1060 \\
\hline $\mathrm{B}$ & N 435,4541 & E 528,800 & CTD 12 & 942 & $23 / 08 / 2014$ & $07: 33: 28$ & 878 \\
\hline \multirow{3}{*}{$\mathrm{C}$} & \multirow{3}{*}{ N 436,2828} & \multirow{3}{*}{ E 529,0518} & CTD 2 & 736 & $11 / 08 / 2014$ & $06: 35: 59$ & \\
\hline & & & CTD 7 & 845 & $21 / 08 / 2014$ & $14: 22: 31$ & \\
\hline & & & CTD 13 & 855 & $23 / 08 / 2014$ & $08: 14: 18$ & 800 \\
\hline \multirow{2}{*}{$\mathrm{D}$} & \multirow{2}{*}{ N 436,8421} & \multirow{2}{*}{ E 529,1254} & CTD 3 & 781 & $11 / 08 / 2014$ & $07: 13: 58$ & \\
\hline & & & CTD 8 & 786 & $21 / 08 / 2014$ & 15:00:20 & \\
\hline \multirow{4}{*}{$\mathrm{E}$} & \multirow{4}{*}{ N 437,1532} & \multirow{4}{*}{ E 529,0063} & CTD 4 & 755 & $12 / 08 / 2014$ & $06: 34: 29$ & \\
\hline & & & CTD 6 & 630 & $20 / 08 / 2014$ & $15: 49: 42$ & \\
\hline & & & CTD 9 & 750 & $21 / 08 / 2014$ & $15: 31: 22$ & \\
\hline & & & CTD 14 & 755 & $23 / 08 / 2014$ & 08:51:11 & 680 \\
\hline \multirow{2}{*}{$\mathrm{F}$} & \multirow{2}{*}{ N 437,7192} & \multirow{2}{*}{ E 528,8605} & CTD 5 & 581 & $12 / 08 / 2014$ & 07:09:51 & \\
\hline & & & CTD 10 & 626 & $21 / 08 / 2014$ & 16:04:51 & \\
\hline G & N 438,1346 & E 528,7487 & CTD 17 & 349 & $23 / 08 / 2014$ & $10: 29: 35$ & 310 \\
\hline \multirow{2}{*}{$\mathrm{H}$} & \multirow{2}{*}{ N 438,7006} & \multirow{2}{*}{ E 528,6971} & CTD 18 & 110 & $23 / 08 / 2014$ & 10:51:59 & 77 \\
\hline & & & CTD 23 & 149 & $26 / 08 / 2014$ & 15:36:05 & \\
\hline I & N 439,5810 & E 528,6971 & CTD 19 & 102 & $23 / 08 / 2014$ & 11:11:04 & 80 \\
\hline $\mathrm{J}$ & N 4310,8735 & E 528,6812 & CTD 20 & 92 & $23 / 08 / 2014$ & $11: 32: 27$ & 75 \\
\hline $\mathrm{K}$ & $\mathrm{N} 437,5810$ & E 527,9242 & CTD 15 & 770 & $23 / 08 / 2014$ & 09:28:05 & 520 \\
\hline \multirow{2}{*}{$\mathrm{L}$} & \multirow{2}{*}{ N 437,9459} & \multirow{2}{*}{ E 526,4985} & CTD 16 & 100 & $23 / 08 / 2014$ & 09:53:27 & 60 \\
\hline & & & CTD 22 & 110 & $26 / 08 / 2014$ & 15:08:47 & \\
\hline \multirow{3}{*}{ M } & \multirow{3}{*}{ N 437,194} & \multirow{3}{*}{ E 527,732} & CTD 1 & 573 & $10 / 08 / 2014$ & 08:43:49 & \\
\hline & & & CTD 21 & 534 & $26 / 08 / 2014$ & $14: 40: 56$ & \\
\hline & & & CTD 24 & 502 & $27 / 08 / 2014$ & $15: 25: 47$ & \\
\hline
\end{tabular}




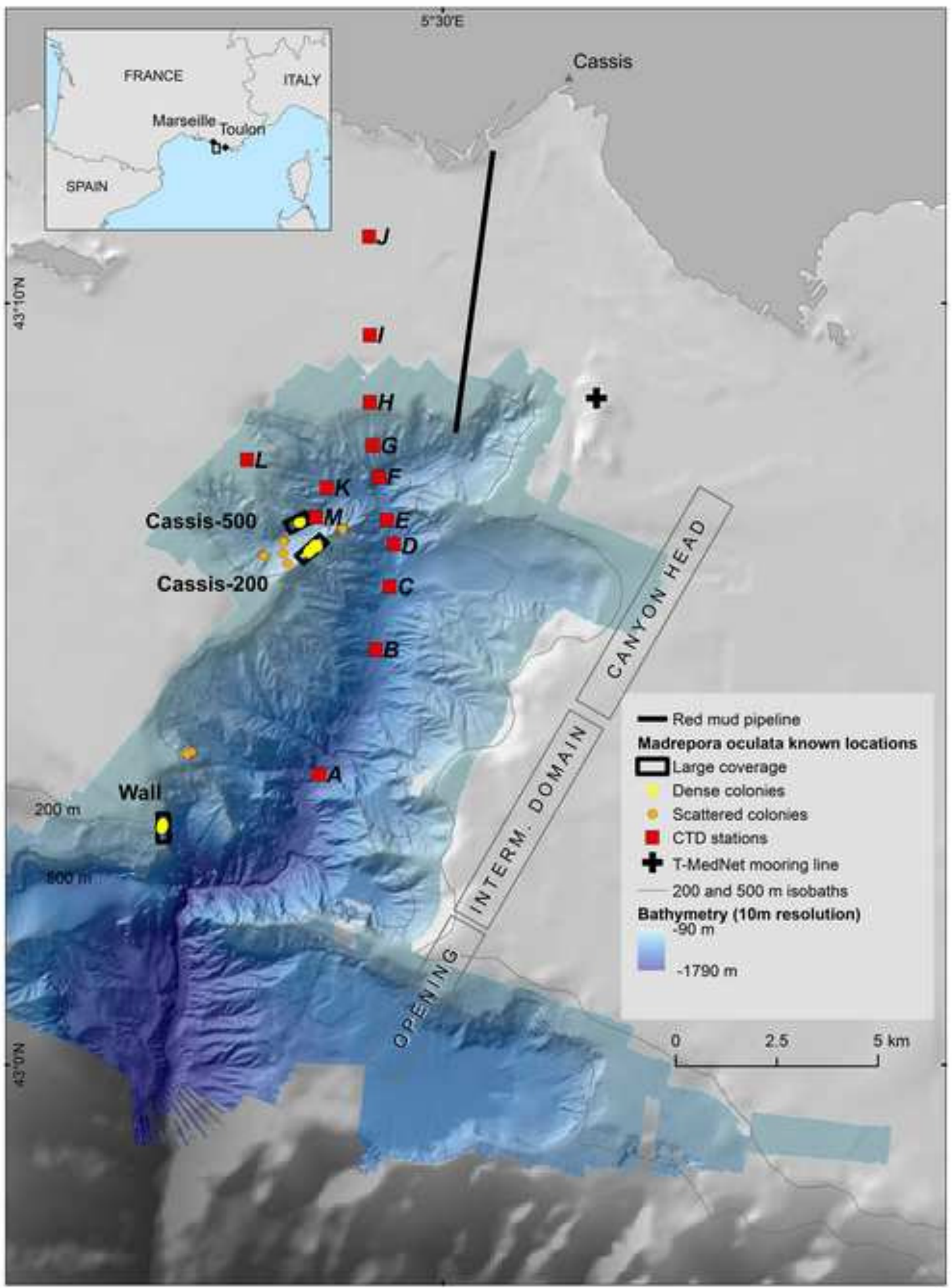



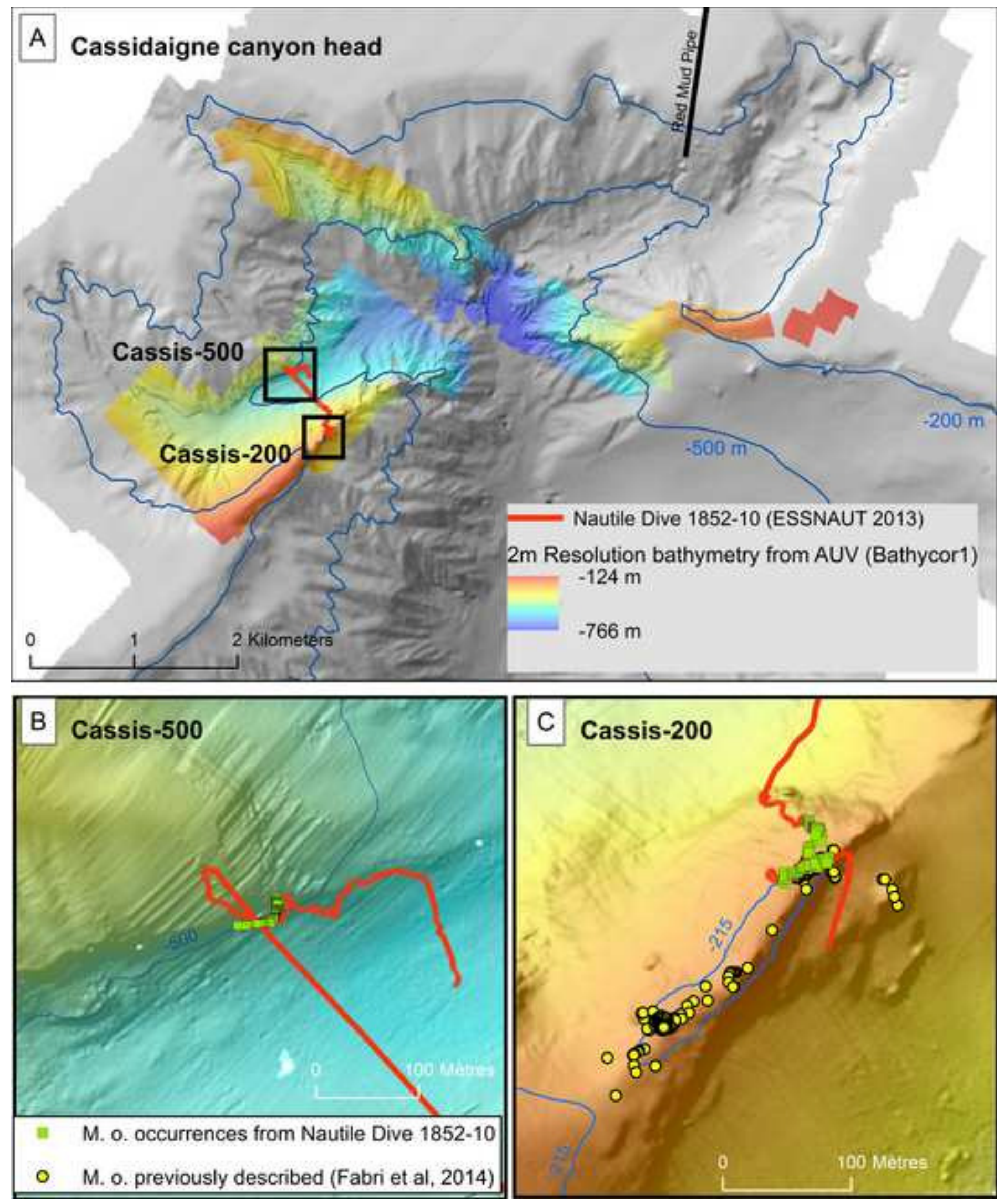

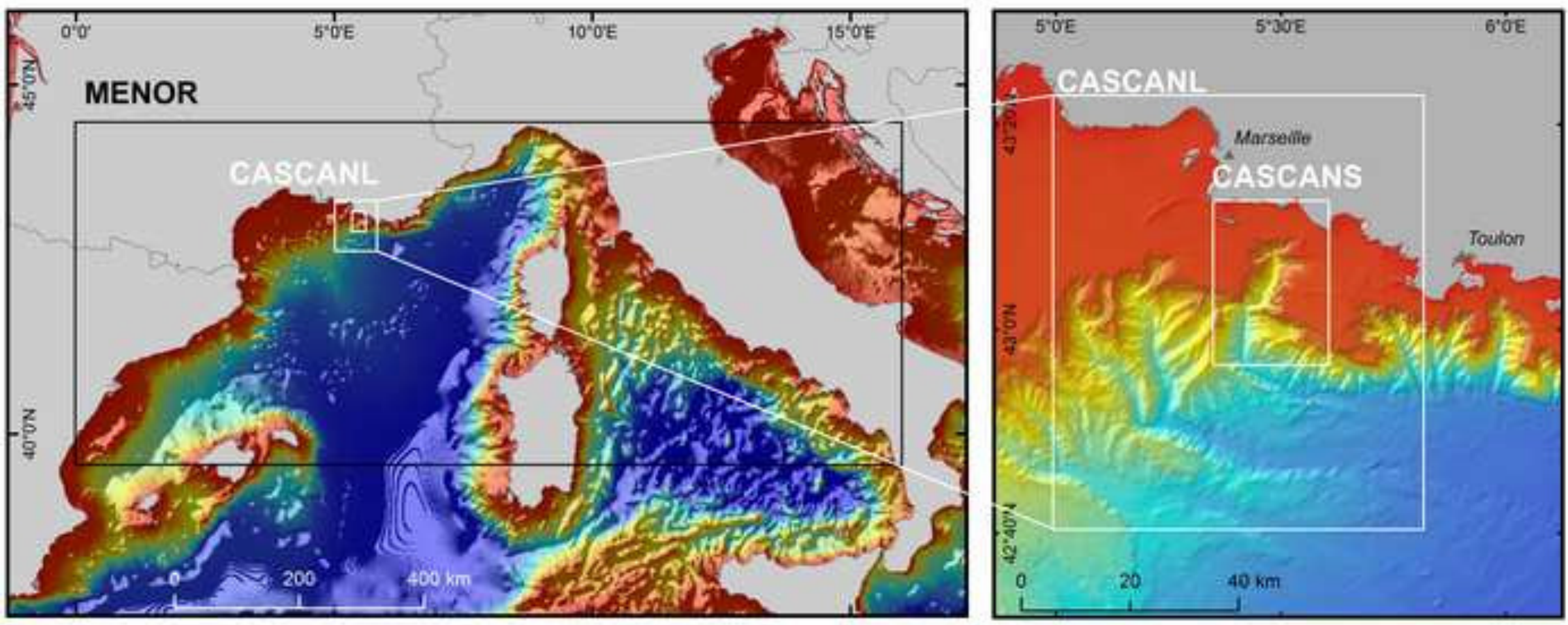

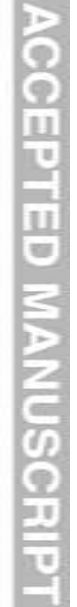




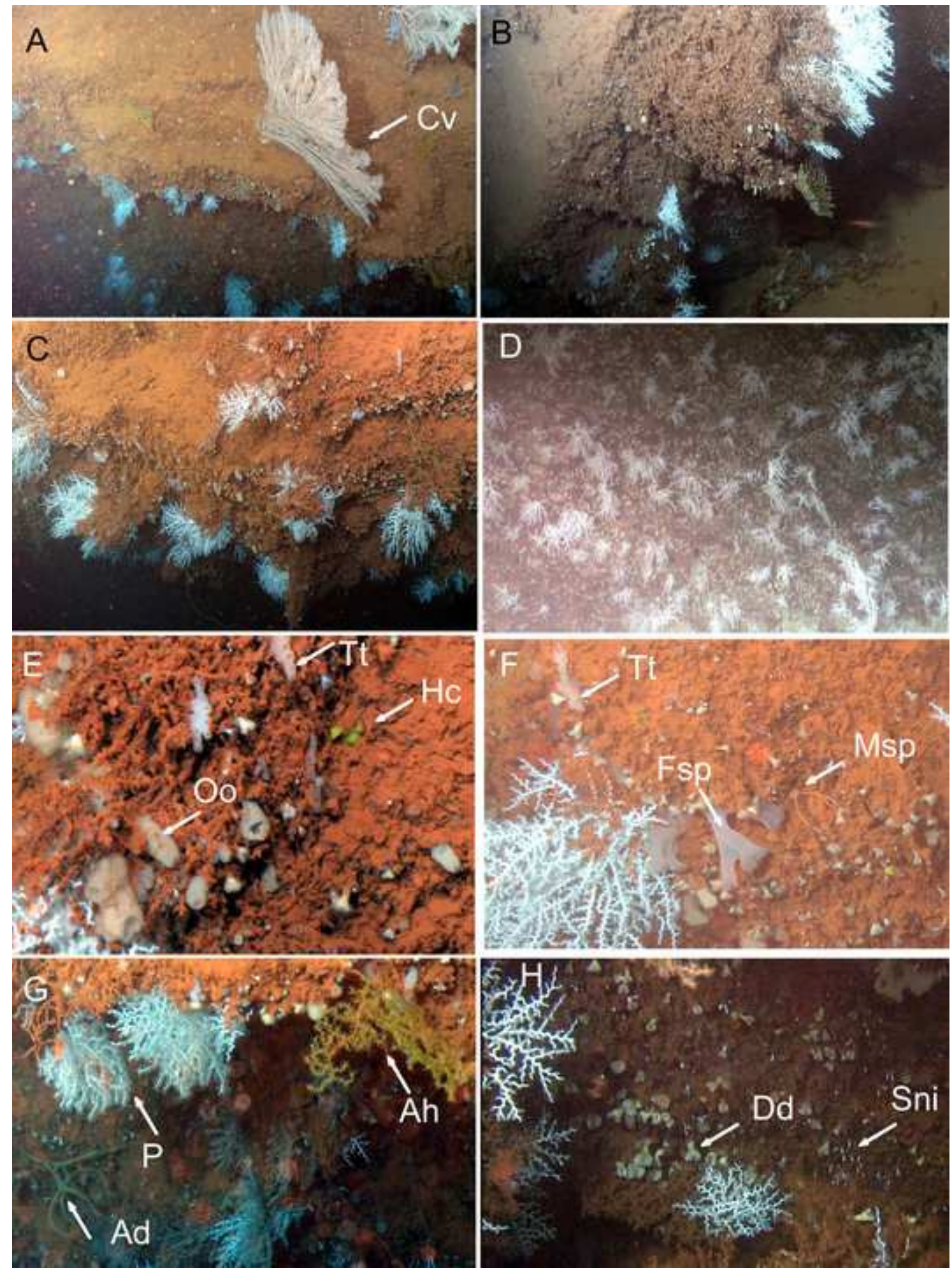

\section{.}
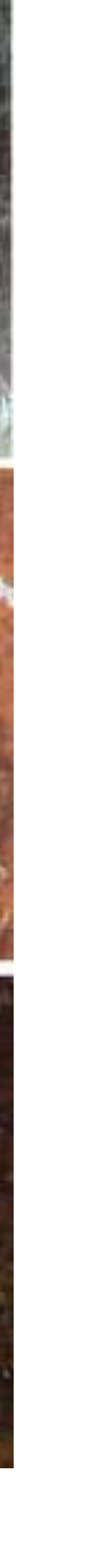

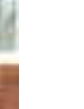

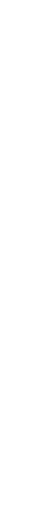



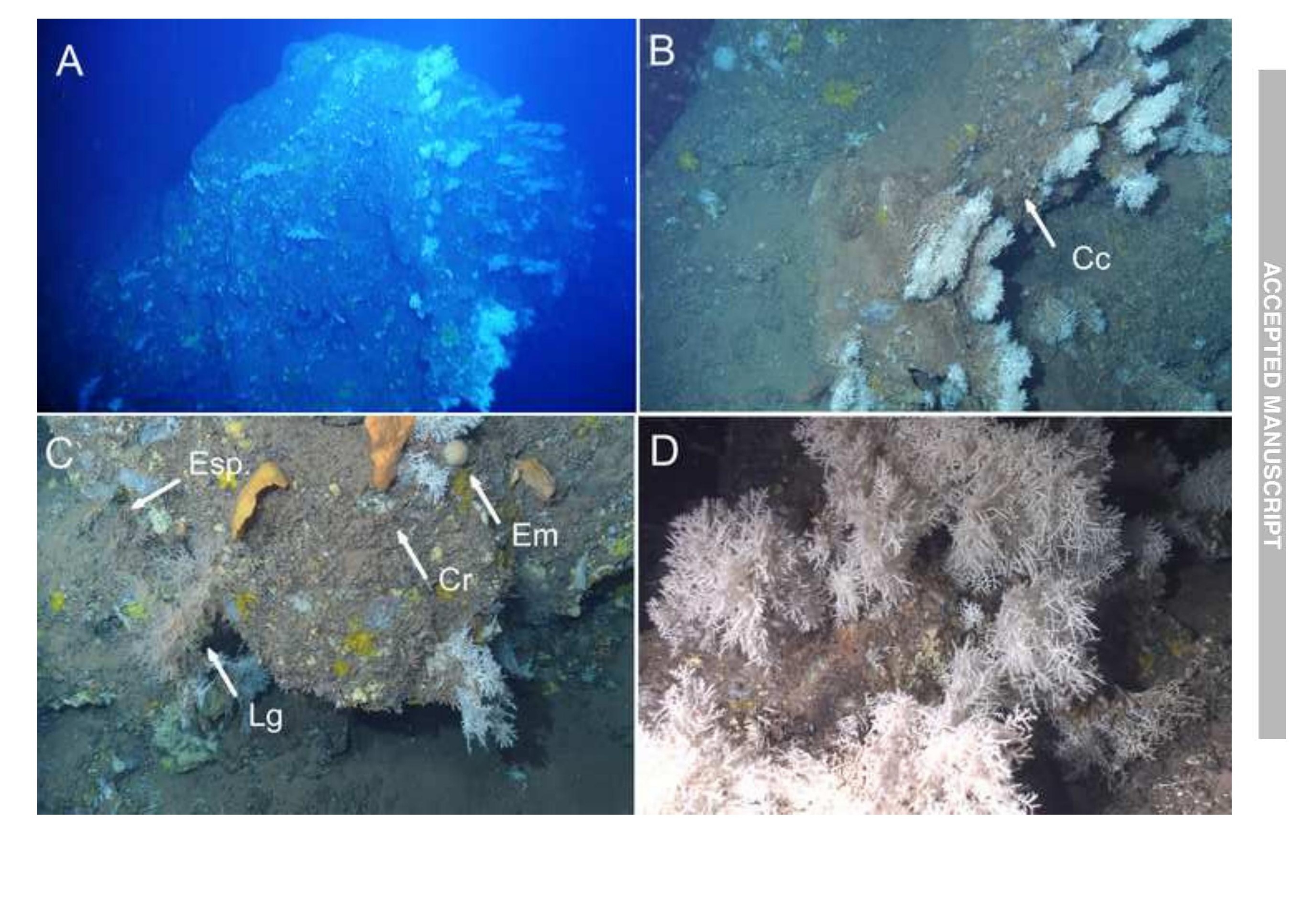

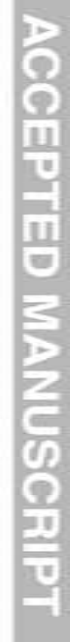




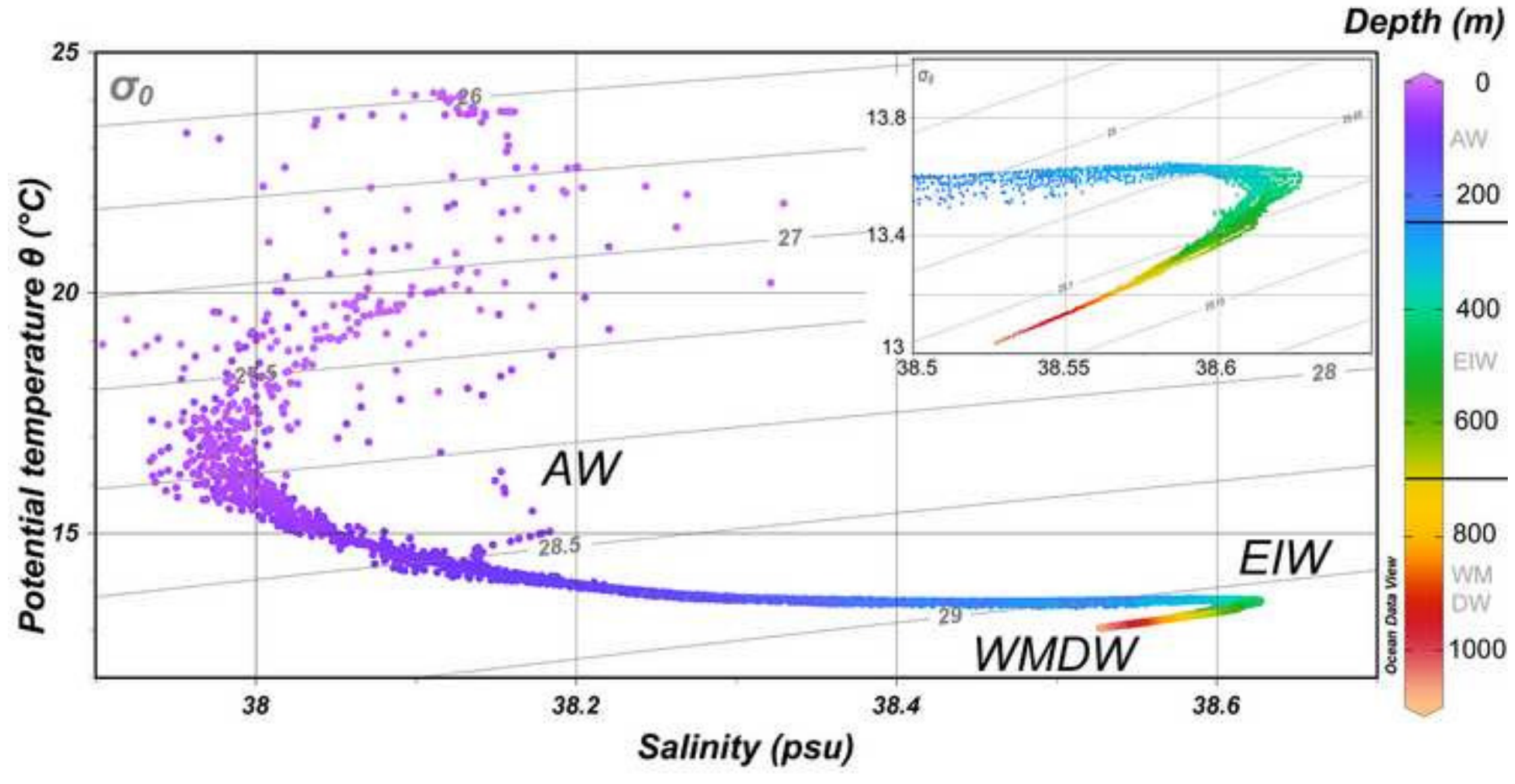


Depth (m)

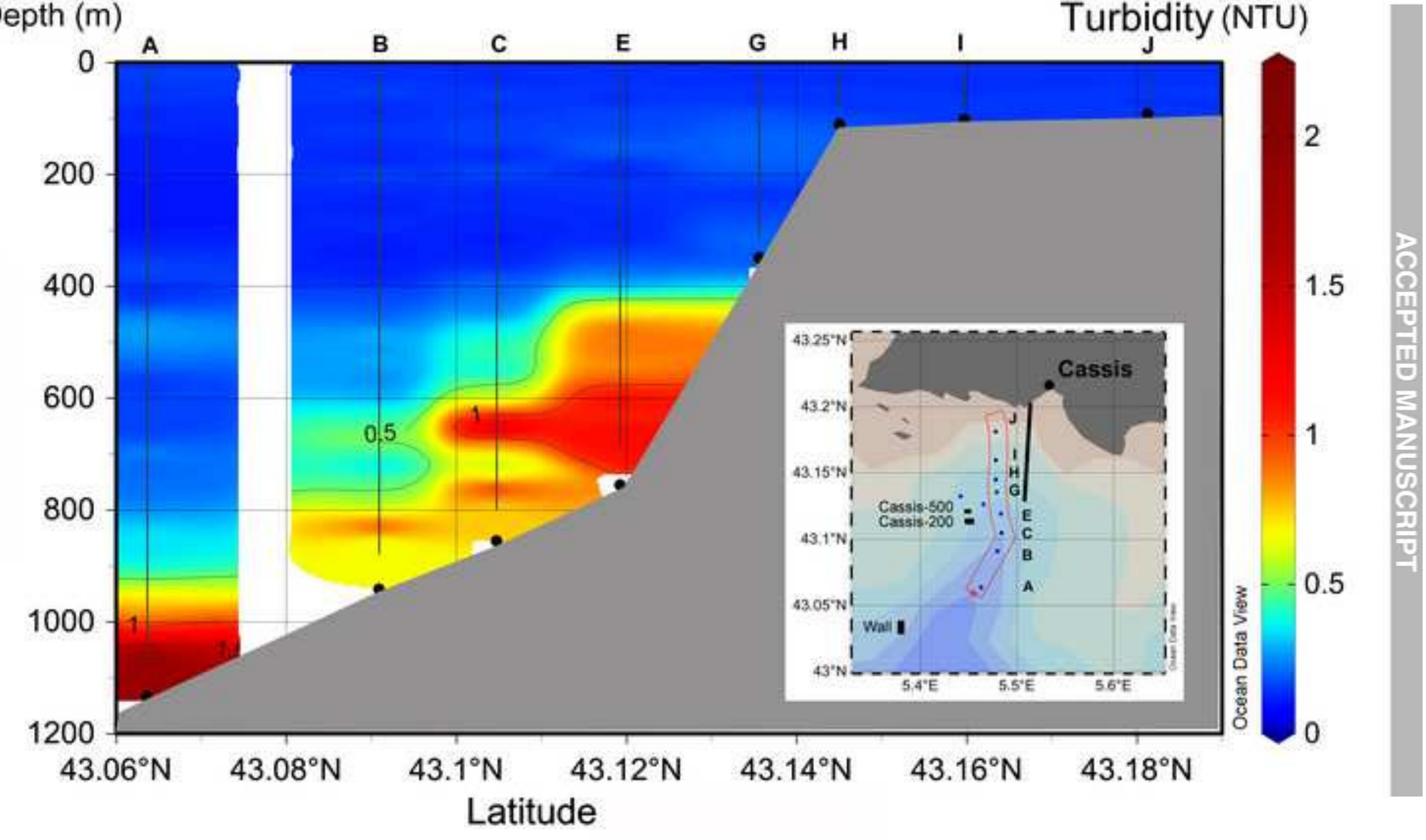

Turbidity (NTU) 

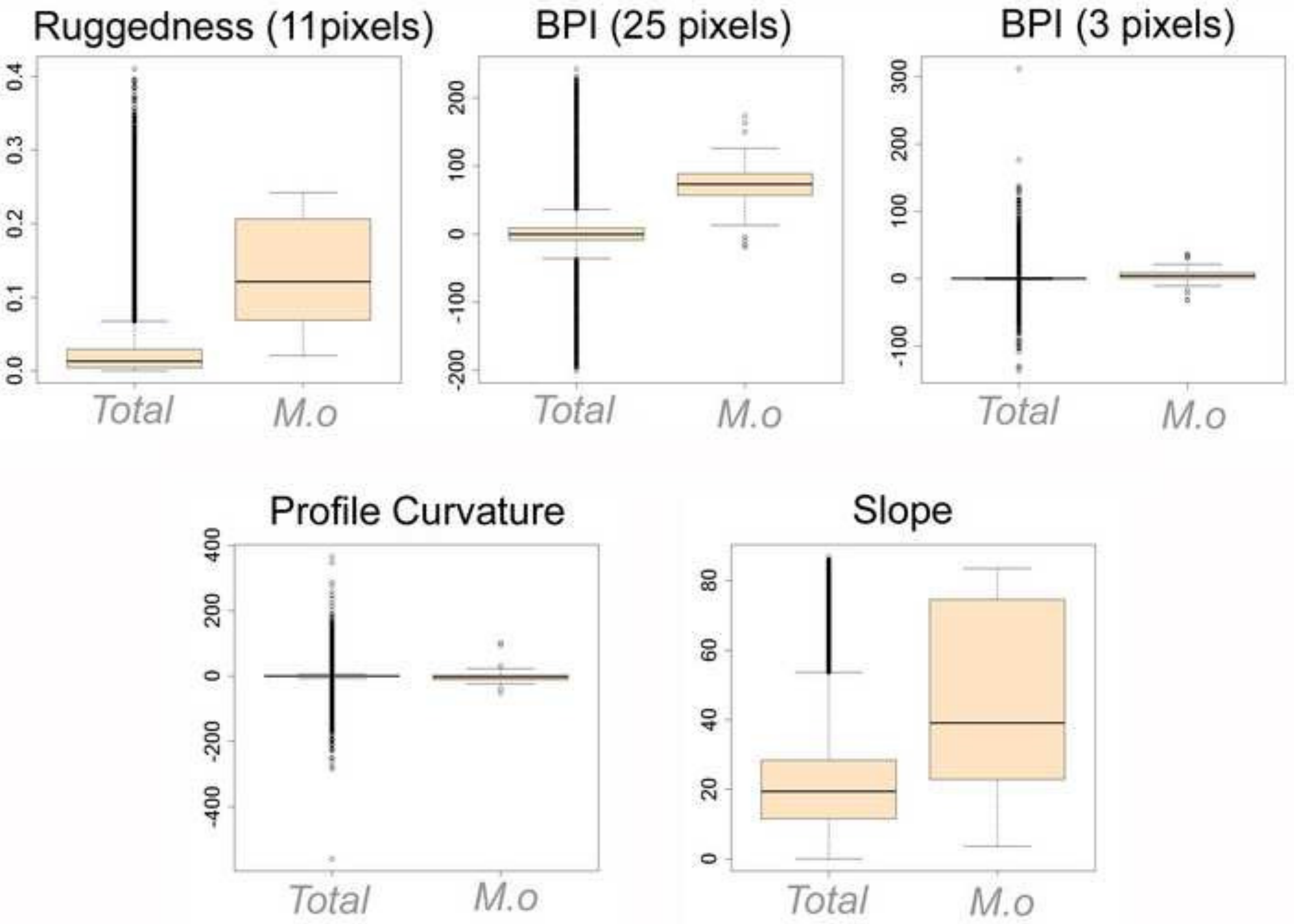

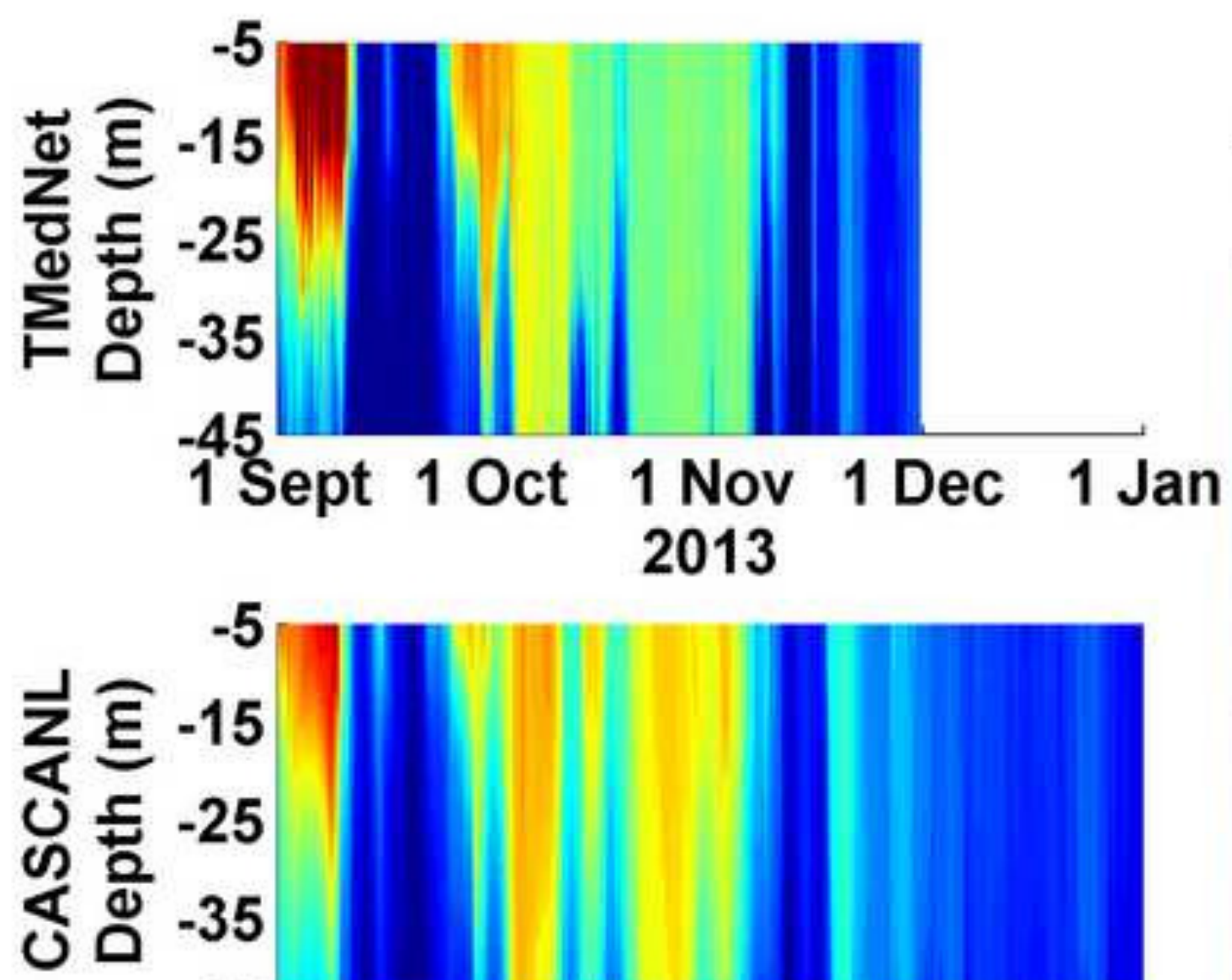

$-45$

1 Sept 1 Oct 1 Nov 1 Dec 1 Jan 2013

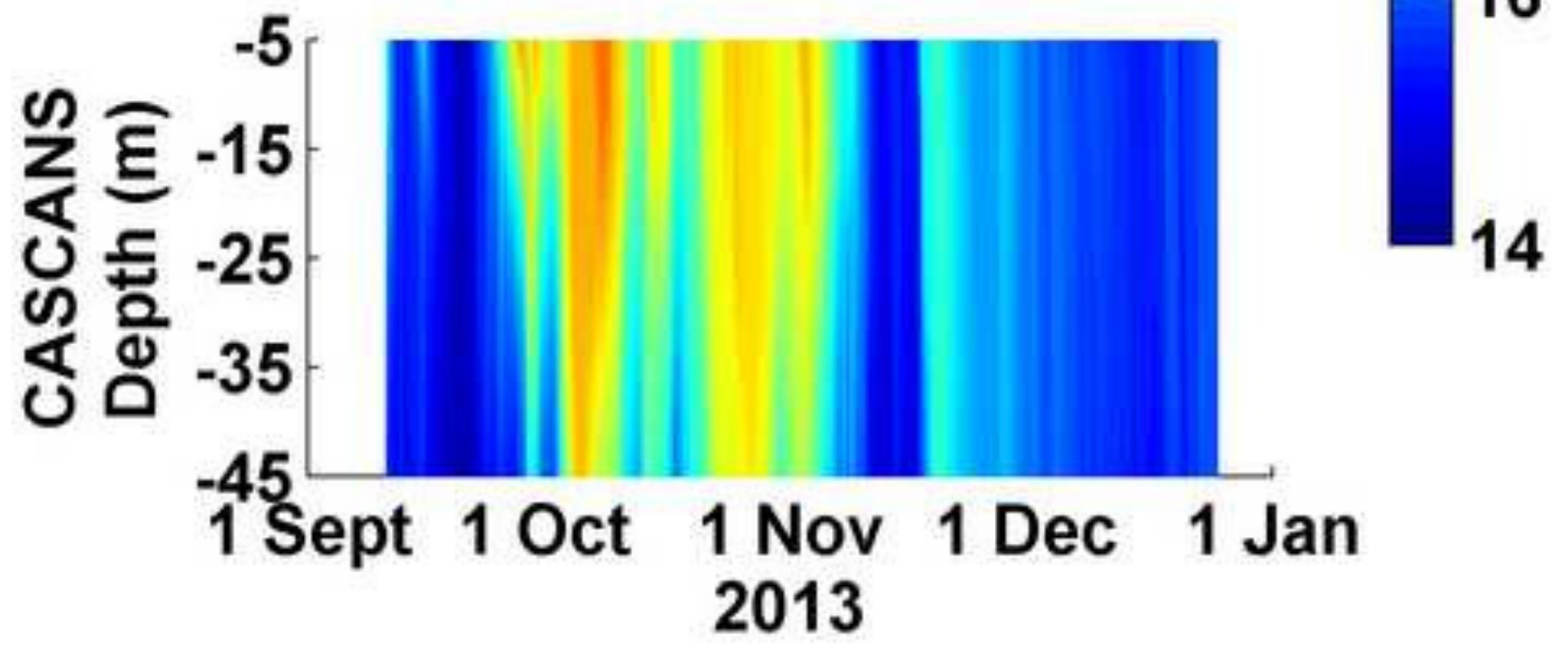

16 

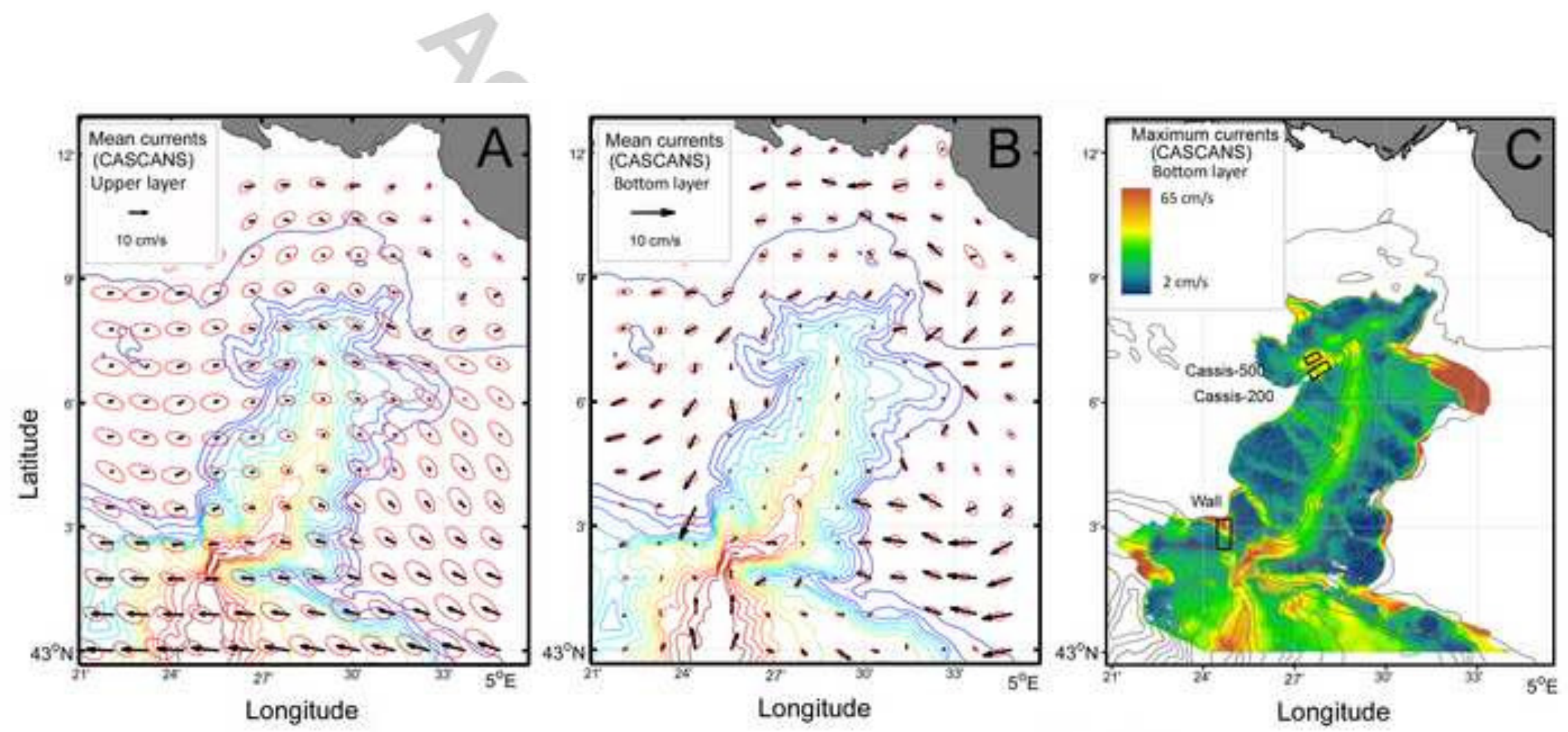

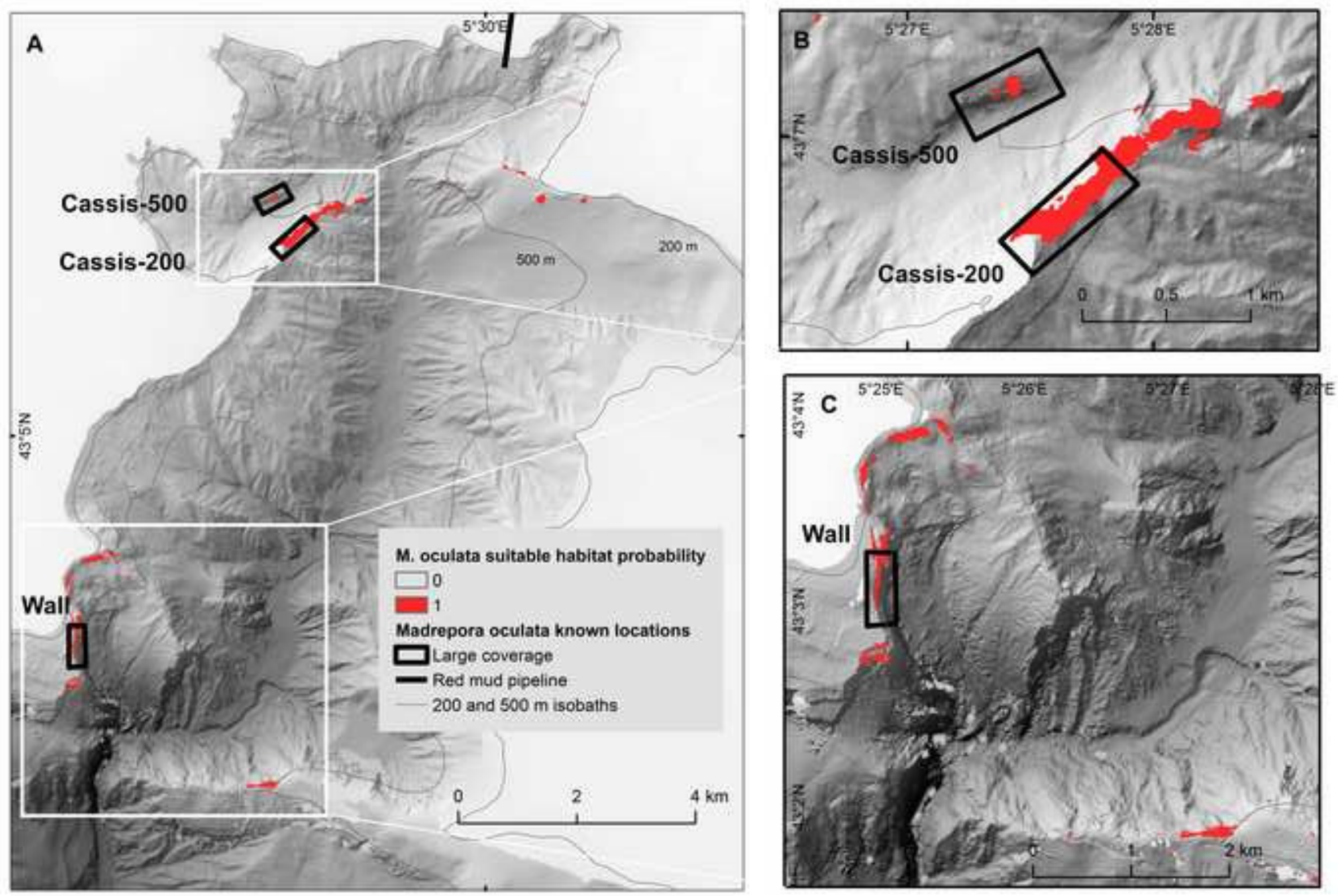

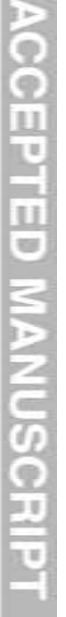

